IZA DP No. 6595

Gender Discrimination in the Australian

Graduate Labour Market

Ian W. Li

Paul W. Miller

May 2012 


\title{
Gender Discrimination in the Australian Graduate Labour Market
}

\author{
Ian W. Li \\ Curtin University \\ and University of Western Australia \\ Paul W. Miller \\ Curtin University \\ and IZA
}

Discussion Paper No. 6595

May 2012

IZA
P.O. Box 7240
53072 Bonn
Germany

Phone: +49-228-3894-0

Fax: +49-228-3894-180

E-mail: iza@iza.org

\begin{abstract}
Any opinions expressed here are those of the author(s) and not those of IZA. Research published in this series may include views on policy, but the institute itself takes no institutional policy positions.

The Institute for the Study of Labor (IZA) in Bonn is a local and virtual international research center and a place of communication between science, politics and business. IZA is an independent nonprofit organization supported by Deutsche Post Foundation. The center is associated with the University of Bonn and offers a stimulating research environment through its international network, workshops and conferences, data service, project support, research visits and doctoral program. IZA engages in (i) original and internationally competitive research in all fields of labor economics, (ii) development of policy concepts, and (iii) dissemination of research results and concepts to the interested public.
\end{abstract}

IZA Discussion Papers often represent preliminary work and are circulated to encourage discussion. Citation of such a paper should account for its provisional character. A revised version may be available directly from the author. 


\section{ABSTRACT}

\section{Gender Discrimination in the Australian Graduate Labour Market}

This paper examines gender discrimination in the Australian graduate labour market, using data from the Graduate Destination Surveys 1999-2009. A framework of analysis provided by the overeducation/required education/undereducation literature is applied. A smaller gender wage gap is found for university graduates than that reported for all workers in earlier studies. It is shown, however, that the gender wage gap widens with the age at graduation. This pattern is argued to reflect the influence of the mismeasurement of actual labour market experience in the conventional education and experience earnings equation on the standardised gender pay gap. Female graduates are less likely to be overeducated, compared to male graduates. Overeducation, while associated with substantial penalties, is not a substantial contributor to the gender wage gap.

JEL Classification: J24, J31, J70

Keywords: gender, graduates, overeducation, discrimination

Corresponding author:

Ian W. Li

School of Population Health

The University of Western Australia

M431, 35 Stirling Hwy

Crawley, WA 6009

Australia

Email: ian.li@uwa.edu.au

\footnotetext{
* The authors are grateful to Graduate Careers Australia for data provision, and to two anonymous referees for helpful comments. Li acknowledges financial assistance in the form of an Australian Postgraduate Award, and Miller acknowledges financial assistance from the Australian Research Council. The views expressed in this paper are those of the authors, and should not be attributed to Graduate Careers Australia.
} 


\section{Gender Disc rimination in the Australian Graduate Labour Market}

\section{Introduction}

In a meta-analysis of 263 international empirical studies spanning from the 1960s to the late 1990s, Weichselbaumer and Winter-Ebmer (2005) reported a halving of the gender wage gap, from 65 per cent to 30 per cent. This decline was attributed by these authors to the equalisation of human capital endowments. The typical Blinder-Oaxaca wage residual, or the gender wage gap usually attributed to labour market discrimination, was reported to have been unchanged over time.

The gender wage gap in Australia has also fallen considerably since the 1960s (see, for instance, Borland, 1999; Gregory, 1999). In contrast to the situation overseas, however, the change in Australia appears in large part to be due to a decrease in the size of the BlinderOaxaca wage residual, following the Equal Pay decisions of 1969 and 1972, and the Sex Discrimination Act of 1984 (Miller, 1994). Nevertheless, a standardised gender pay gap of up to 15 per cent remains (Borland, 1999).

Recent studies of this gender pay gap have documented a number of striking patterns. First, it has been established that the gender pay gap is quite modest among 15-19 year olds, and increases with age (ABS, 2007). The minor gender wage gap among 15-19 year olds could be due to minimum wage effects. The male minimum wage was extended to females in 1974. Under this explanation, it would be expected that there would be a reasonably sharp jump in the gender pay gap between youth and older workers, as one moves from a wagesetting regime where minimum rates of pay are more prevalent to a situation where wages are more likely to be above the minimum. An alternative explanation, that draws on a more gradual widening of the female wage disadvantage with age, is that the measure of labour market experience included in the conventional education and experience earnings equation becomes increasingly error prone among older workers. 
A second pattern evident in the studies is that the gender wage gap is larger among the better educated than it is among the less-well educated (OECD, 2011). The greater wage disadvantage experienced by tertiary educated females compared to their counterparts without post-secondary qualifications is presumably a reflection of the glass ceiling effect reported by Kee (2006). This may also be linked to institutional factors. The graduate labour market is a relatively high-wage market, with average starting salaries well above the average for non-graduates of a similar age. Preston (2001, p. 199) argues that 'Females benefit from institutional regulation (e.g. minimum wage laws) when it comes to wage determination'. It would therefore be expected that as institutional regulation would have little impact on the graduate labour market the graduate gender wage gap could be significant.

From this perspective, a study of gender wage discrimination in the graduate labour market has much appeal. It will permit assessment of the relative strengths of the countervailing 'young age' and 'high level of education' influences on the gender wage gap. This is one aim of the current paper. Moreover, the analyses will be undertaken using perspectives from the overeducation/required education/undereducation literature. This seems particularly apt, given the changes in the higher education participation rates of males and females in recent decades. Up to the early 1970s, the participation rate of males at most levels of education exceeded that of females (Le and Miller, 2002). Since then, however, the relative standing has been reversed. For example, a report by education consultants Strategy and Research Policy in Education (2012), drawing on data from the Australian Bureau of Statistics, finds that in 2011 the higher education attainment rate was around 40 and 30 per cent for female and male Australians aged 25 to 34 years old, respectively. This greater representation of females among graduates raises the question of whether it is reflected in females being more likely to be overeducated. In other words, given that females are more likely to engage in higher education, it might be that larger proportions of them are in jobs 
which are not suited to their level of educational attainment. Related to this, it is of interest to see how individuals fare in the graduate labour market if they are not matched properly to their jobs, whether any penalty to such education-occupation mismatch differs for males and females, and whether the overeducation phenomenon contributes to the gender pay gap in the graduate labour market. These seemingly important issues are addressed below.

The rest of the paper is organised in the following manner. Section 2 reviews the literature on overeducation, with an emphasis on studies in this literature that examine gender differences. The gender differences in educational mismatch are discussed in the context of the 'job search' hypothesis (Frank, 1978). Section 3 describes the data and presents the methodology. Section 4 presents and discusses the results of the estimations. Finally, a conclusion is offered in section 5.

\section{Literature Review}

\section{Over-, Required and Under-Education (ORU)}

There is a well-developed literature on the incidence and earnings effects of Over-, Required, and Under-education (ORU). This literature has its origins in Freeman (1976), though the empirical framework that is now commonly used is due to Duncan and Hoffman (1981). The key concept considered is that while most individuals will be 'matched' to their jobs on the basis of their education, some will not be. Individuals with education in excess of that required by the job are considered 'overeducated'. Conversely, individuals who have less education than that required for the job are taken to be 'undereducated'. The labour market outcomes of matched and mismatched individuals could differ.

Various conceptual frameworks and measurement issues in this literature are discussed in Hartog (2000) and Leuven and Oosterbeek (2011). A discussion of the empirical frameworks which have been used by studies examining ORU can be found in McGuinness 
(2006). Each of these studies offer a summary of the empirical findings in the overseas literature, while a survey of the Australian literature is presented in Miller (2007). Five main findings have emerged from the empirical studies. The first finding relates to the definition of educational mismatch. Generally, three approaches have been used to define educational mismatch: i) job analysis; ii) worker self-assessment; and iii) realised matches. The job analysis and realised matches approaches rely on objective measures of overeducation, while the worker self-assessment uses the worker's subjective assessment of educational (mis)match. The objective approaches, which will be used in the analysis below, are explained in more detail in section 3. A number of studies have shown that whereas the estimated wage effects are robust regardless of the approach adopted, the measured incidence of overeducation depends on the definition of mismatch employed (Hartog, 2000).

The second finding relates to the incidence of educational mismatch in the labour market. Hartog's (2000) review found that, on average, a substantial 40 per cent of workers are not correctly matched to their jobs. Third, while the earnings returns to being overeducated are positive, they are less than the earnings returns on required education. Returns to surplus years of education typically range from one-half to two-thirds of the returns to years of required education. Fourth, workers who are undereducated earn more than their peers with the same level of education but who are working in a correctly matched (and hence lower level) job. This might be attributed to the presence of unobservable factors, such as innate ability or the propensity to work hard, such that these undereducated individuals are able to enter jobs which they would otherwise be unqualified for. Fifth, it has been reported that there are differences between males and females in both the incidence of education-occupation mismatch, and the wage effects of such mismatch. 


\section{The J ob Search Hypothesis}

Studies of gender differences in the incidence and effects on wages of educationoccupation mismatch have been guided by several theoretical arguments. One of these is the job search hypothesis. This proposes that females are secondary income earners in the household (Frank, 1978) and so are more constrained in their job search. This more limited job search is expected to result in females being more likely to be mismatched, and also to incur a larger wage penalty than males from being overeducated. Buchel and Battu (2003) report results that are consistent with this description of the labour market, in that married women were found to be more likely to be overeducated, relative to men or unmarried women. This was particularly so in small, localised labour markets.

However, most studies reject the job search hypothesis. Vahey (2000), for example, restricted his sample to unmarried females (who are unlikely to be a secondary income earner) who were based in the metropolitan area, and compared the ORU earnings effects in this sample to those for the female sample without these restrictions. Vahey (2000) found that most of his ORU dichotomous variables were statistically insignificant, and the two that were significantly different from zero exhibited impacts which were not reconcilable with the job search theory. Similarly, McGoldrick and Robst (1996) also find no indication that overeducated females are penalised more than males due to geographical constraints in their job search.

A second theoretical perspective is offered by Robst (2007), based on consideration of both the supply- and demand-side factors that could lead to educational mismatch. Supplyside factors include career-oriented ones, such as accepting a promotion, or amenity- and constraint-related reasons, such as accepting a job nearer to home. The demand-side factors typically refer to the inability to find a job that matches the qualification possessed. Robst (2007) found that males were more likely to be overeducated due to career-related reasons, 
while females were more likely to be mismatched due to family-related reasons, although he acknowledges the possibility of reporting bias due to social norms.

\section{ORU Differences by Gender in the Graduate Labour Market}

A number of studies have examined gender differences in educational mismatch in the graduate labour market. There is disagreement in the research findings of these studies, and even within particular studies. Thus, Kler (2005) examined the Australian graduate labour market. He reported that, using the realised matches approach, 38 per cent of female graduates were overeducated, compared with 46 per cent of male graduates. When the job analysis approach was used, however, there was no difference between males and females in the incidence of overeducation. ${ }^{1}$ McGuinness and Bennett (2007) studied graduate overeducation in Northern Ireland and found that females were more likely to be overeducated than men in their first job, although the gap was narrowed six years later.

Battu et al. (2000) used three different measures of overeducation in their study of the UK graduate labour market. The two subjective measures used revealed that males were more likely to be overeducated, while the realised matches approach yielded the opposite finding. The absence of a clear pattern regarding the relative importance of overeducation for males and females seems to reflect both the measurement issue noted earlier, and differences across the labour markets of the various countries.

The penalties to overeducation among graduates have also been found to differ by gender. Again there is considerable irregularity in the research findings across studies. McGuinness and Bennett (2007), for example, reported OLS estimated coefficients of -11.3 and -22.8 per cent for overeducated males and females, respectively. This pattern is also

\footnotetext{
${ }^{1}$ A comparison of these results for graduates with findings from studies of all workers suggests there are outcomes specific to particular groups. Thus, another Australian study by Voon and Miller (2005), which covered all workers, reported that the incidence of mismatch was 29.5 per cent for males and 32.1 per cent for females.
} 
evident in the study by Battu et al. (2000), though the difference by gender works in the opposite direction in an earlier study by Dolton and Vignoles (2000). Kler’s (2005) study of the Australian graduate labour market reported greater returns to surplus education for females compared to males. These studies do not focus on the gender pay gap, or on the contribution that ORU status can make to this in the graduate labour market. These issues are addressed below.

\section{The Blinder-Oaxaca Decomposition}

The decomposition method used in the examination of earnings differentials between sub-groups of the population was developed in Blinder (1973) and Oaxaca (1973). It has come to be known as the Blinder-Oaxaca decomposition. In its most widely used form, the decomposition involves the estimation of a standard Mincerian earnings equation separately for the sub-groups of interest. This equation can be expressed as:

$\log w_{i}^{j}=\alpha_{0}^{j}+\alpha_{1}^{j} X_{i}^{j}+\epsilon_{i}^{j}, i=1, \ldots, n ; j=m$ for male and $f$ for female

where $\log w_{i}$ denotes the earnings of individual $i$, expressed in logarithmic format, and $X_{i}$ denotes the vector of characteristics hypothesised to impact on earnings. The superscript $j$ identifies the membership of individual $i$ in the male or female groups. The decomposition can thus be written as:

$$
\overline{\log w}^{m}-\overline{\log w}^{f}=\hat{\alpha}_{1}^{m}\left(\bar{X}^{m}-\bar{X}^{f}\right)+\left(\hat{\alpha}_{1}^{m}-\hat{\alpha}_{1}^{f}\right) \bar{X}^{f}+\left(\hat{\alpha}_{0}^{m}-\hat{\alpha}_{0}^{f}\right)
$$

The use of the estimated coefficients, as well as the mean values of variables for both groups, thus allows for a decomposition of the difference between the mean wages of the sub- 
groups into two portions. The first term on the right hand side of equation (2) attributes earnings differences to differences in endowments or characteristics, and is considered the 'explained' portion of the earnings gap. In this version of the decomposition the differences in endowments are evaluated using the male coefficients. This implies that the male wage structure is the wage structure that would prevail in the absence of discrimination, that is, it is the non-discriminatory norm. The second term on the right hand side of equation (2) attributes earnings differences to differences in coefficients, or returns to human capital characteristics. This portion thus implies unequal treatment of productivity characteristics in the labour market. The coefficient effects, together with the difference between the two constant terms in the estimation as expressed by the third term, form the unexplained portion of the earnings differential. These effects are generally attributed to discrimination in the labour market.

There are also alternative decomposition methods which involve a three-fold decomposition of the earnings difference (see, for example, Jones and Kelley 1984 for a discussion). These decomposition methods involve the addition of an interaction term which captures the joint effect of differences in endowments and coefficients. The interpretation of this interaction term differs, depending on the view of the labour market adopted. The different treatments of this interaction term are described in more detail in the following section. The two-fold decomposition appears to be preferred by researchers in the economics discipline, while the three-fold decomposition seems to be preferred by researchers in the sociology discipline.

\section{Measurement Issues with the Blinder-Oaxaca Decomposition}

There are two main measurement issues that have been raised in the decomposition literature. The first issue lies in the choice of the non-discriminatory earnings structure. That 
is, the results of the decomposition of equation (2) above would be dependent on whether the male or female wage structure is used as the non-discriminatory wage structure. This issue has been raised by a number of researchers, including Jones and Kelley (1984), Cotton (1988), Neumark (1988) and Oaxaca and Ransom (1994). The available research demonstrates that the results of wage decompositions are sensitive to the choice of the nondiscriminatory benchmark. In Ferber and Green (1982), for instance, adopting the female wage structure as the non-discriminatory norm yielded an estimate of two per cent of the earnings differential as the discriminatory component. When the male wage structure was adopted, however, discrimination accounted for 70 per cent of the wage differential.

From a theoretical perspective, the choice of the non-discriminatory benchmark depends on the wage structure that is thought to prevail in the absence of discrimination. Where rates of pay in the post-discrimination era are likely to be determined by the wages of the higher earning group, then these should be used to evaluate the endowment effect in the decomposition. ${ }^{2}$ In contrast, where rates of pay in the post-discrimination era are likely to be determined by the wages of the lower earning group, then it is the lower earning group's pay that should be used to evaluate the endowment effect in the decomposition. ${ }^{3}$ The use of the alternative pay structures in the decomposition also provides a basis for reconciling the twoway and three-way decompositions. Hence, as Jones and Kelley (1984) show, the use of the pay structure of the higher earning group as the non-discriminatory norm in the two-way model is equivalent to adding the interaction term for the three-way model to the endowment component. Similarly, the use of the pay structure for the low earning group in the simple

\footnotetext{
${ }^{2}$ A typical approach in the literature uses both the male and female wage structures as the non-discriminatory wage structure in alternative decompositions, and the average results from the analyses are reported.

3 Jones and Kelley (1984) distinguish these decompositions by addressing how one would remove the endowment effect: by reducing any greater endowment of the higher earning group (removing a privilege under their privilege model) or by enhancing any inferior set of endowments of the lower earning group (removing a deficit under their deprivation model). Economists generally view the endowments of the two groups as equalising over the longer term in response to the removal of any differences in pay (see Cotton, 1988).
} 
decomposition is equivalent to adding the interaction term for the three-way model to the discrimination component.

The idea that the post-discrimination wage structure would be given by one of the two prevailing wage structures has been argued to be inconsistent with the notion of market determined pay structures. The pay structure that emerges in the post-discrimination era would presumably be somewhere in between the original two sets of pay. Neumark (1988), for example, assumes that both nepotism and discrimination occur at the same time, and the choice of the non-discriminatory structure should consider both scenarios in tandem. He thus suggests the use of a pooled wage structure as the non-discriminatory wage structure, where, in this instance, the pooled wage regression does not include a gender intercept shift. Cotton (1988) proposed the use of a weighted average of the two original wage structures with the weights being given by the employment shares of the groups being examined. The methodology in the Neumark-Cotton approach thus allows for the identification of the portions in the earnings differential that are attributable to nepotism and discrimination.

In a further refinement of this approach, Fortin (2008) shows that the coefficients in the pooled regression could overstate the effects of variables which vary markedly across both groups. ${ }^{4}$ To overcome this, Fortin (2008) suggests the inclusion of a gender intercept shift in the pooled wage regression (see Fortin, 2008, p. 898). ${ }^{5}$ Fortin’s (2008) method allows for the attribution of the gender wage gap to nepotism and discrimination, and is similar to Neumark (1988) and Cotton (1988) in that sense. The Fortin (2008) method appears to represent the preferred approach in the recent literature. An attractive feature of Fortin's (2008) approach is that it is fully compatible with the classic pooled regression approach which includes a dummy variable for the disadvantaged group. That is, the estimated

\footnotetext{
${ }^{4}$ Fortin (2008) referred to the estimated effects for unionisation and schooling in Neumark (1988), which were larger for the pooled sample compared to the corresponding estimates for the male and female samples.

${ }^{5}$ Alternatively, Fortin (2008) suggests weighting the male and female dummy variables by their percentage in the sample to overcome this issue.
} 
‘discriminatory’ portion of the earnings gap from Fortin's (2008) decomposition is equal to the estimated coefficient on the disadvantaged group in a pooled linear regression. Fortin's (2008) examples show that Neumark's (1988) method yields extreme results, and, empirically, her 'regression-compatible’ decomposition gives results more similar to Cotton's (1988) approach.

Another issue that has been raised with the decomposition literature lies with the use of dummy variables in the estimating model. Specifically, it has been shown that the decomposition results for the coefficients effects for particular sets of dummy variables are sensitive to the choice of the base or reference category (Jones, 1983). ${ }^{6}$ As Jones and Kelley (1984) note, the choice of the omitted or benchmark category is often arbitrary, as all available options are usually equally logical. They illustrate this using data on earnings and schooling for males and females in Australia. Specifically, they distinguished five categories of schooling levels, and then omitted the highest or lowest level of schooling in alternative estimations of the gender wage gap. The estimates and conclusions differed markedly, depending on the choice of the benchmark scenario. In particular, the estimated results where university education was the omitted category indicated that females have favourable coefficients effects compared to men. This finding was reversed when primary school education was used as the benchmark in their analysis. Jones and Kelley (1984) argue that the differences are substantial, and that these differences point to vastly different conclusions and therefore remedial policy. ${ }^{7}$

\footnotetext{
${ }^{6}$ The overall wage gap components remain the same, as does the characteristics effects for various sets of variables, though the apparent importance of the characteristics effect for specific dummy variables can vary.

${ }^{7}$ Further, Jones and Kelley (1984) show that the same general issue arises in the case of continuous variables, where the relative size of the components of discrimination in the decomposed wage gap depends on the locations of the zero points of the independent variables in the model. The issue here is that the choice of some, if not most or all, of the zero points of the explanatory variables used in the estimating model is arbitrary. This, in turn, causes the results of the decomposition to be arbitrary and be influenced by the choice of the zero points rather than actual discrimination. Jones and Kelley (1984) illustrated their point using Australian data on income, gender and schooling. They showed that substantial differences emerge in the portion of the income gap attributable to differences in the intercept terms and the estimated coefficients for males and females, when human capital endowments were specified as either years of schooling or age left school. In estimates of the
} 
Oaxaca and Ransom (1999) illustrate the same point in their empirical example looking at the gender wage gap of college professors. The partial contribution of degree type to discrimination was -19.3 log points, and the contribution of constant term differences was 21.9 log points, when 'No Advanced Degree’ was used as the omitted case. Corresponding figures for the alternative specification using ' $\mathrm{PhD}$ ' as the omitted case were -1.1 log points and 3.7 log points. While the overall impact was unchanged at $2.6 \log$ points, the magnitude and importance of the role degree type plays in contributing or alleviating discrimination were vastly different.

More recent studies have proposed solutions to overcome the identification problems stated above. Yun (2005), for instance, suggests an 'averaging approach'. This approach uses the average of the estimated characteristics and coefficients effects obtained using all the various possible reference groups for a particular categorical variable. Further, Yun (2005) illustrated how her approach can be implemented without the need for multiple estimation runs, through a normalisation of the regression equation. ${ }^{8}$

\section{Data and Methodology}

\section{Data}

This study draws on data from the Graduate Destination Surveys (GDS), 1999-2009. The GDS is an annual census of all graduates who have completed the requirements for a qualification award from any Australian university. The GDS is conducted twice yearly, and takes place four months after the completion of a qualification, typically in April and October. While the responsibility for administering the survey lies with individual

model employing the latter 'age left school' specification, they found that the amount of the income gap attributable to the intercept terms dropped by 40 per cent whereas the corresponding amount of the income gap attributable to the coefficients effect is 50 per cent higher. This issue remains unresolved and generally serves as a reminder to exercise caution in making comparisons across studies.

${ }^{8}$ Other approaches have been proposed by Gardeazabal and Ugigdos (2004) and Neilson (2000). However, Yun (2005) notes that identical results are produced by all three approaches and the choice of approach adopted should thus be dictated by efficacy or ease. 
universities, oversight of the GDS, including data coding instructions, lies with Graduate Careers Australia. This dataset covers a wide range of the graduates' characteristics, such as their labour market activities after graduation, personal characteristics, and information on their education (past, and current, if applicable). The response rate for the GDS is reasonably high, with an average response rate of 62 per cent over the years covered in the present study. A study conducted by Guthrie and Johnson (1997) indicated that the GDS can be considered nationally representative of the graduate labour market in Australia.

The data sample was restricted to graduates who were employed in Australia. At the same time, graduates with missing information on the variables used in the analysis, namely, salary, institute of study, level of qualification, age, tenure, double-degree, occupation, sector of employment, industry of employment, length of employment contract, hours of work, mode of study, language background, residency status, gender, and self-employment status, were removed from the sample. The final sample consists of 569,325 observations.

\section{Measurement of Education Mismatch}

In the present study, two different approaches are used to define educational mismatch. First, the job analysis approach is used. This approach uses required levels of education as defined in a job dictionary. As the occupations in the data are coded according to the Australian Standard Classification of Occupations (ASCO), the education standards listed in the ASCO are used as the benchmark to assess if the graduates are overeducated, undereducated, or correctly matched to their jobs. The graduates can be grouped into eight levels of educational attainment: i) diploma; ii) associate degree; iii) bachelor’s pass degree; iv) bachelor’s honours degree; v) graduate diploma; vi) graduate certificate; vii) masters degree; and viii) doctoral degree. There are three levels of required education for the various occupations that can be identified based on the ASCO. These are: i) certificate; ii) diploma; 
and iii) bachelor's pass degree. These required levels of education are the same for males and females. Based on this information, a total of 24 ORU categories were constructed (eight actual education levels times three required levels), with two of these being correctly matched, two undereducated, and the remaining 20 overeducated. Dummy variables for these categories are used in the ORU earnings equation, following the detailed dummy variable specification proposed by Vahey (2000).

In an alternative analysis, information from the 2006 Australian Census of Population and Housing was used to determine the required levels of education separately for males and females. Specifically, this realised matches, or statistical, approach determines the modal levels of education for the various occupations, separately for males and females. Individuals with education levels above the modal levels are deemed to be overeducated. The reverse holds for the undereducated. The required levels of education defined here are more detailed than that from the ASCO, and consist of the following categories: i) year 10; ii) year 12; iii) certificate; iv) diploma, and; v) bachelor's pass degree. Thus, a total of 40 ORU categories can be constructed in this part of the analysis (that is, eight actual levels times five required levels). While the number of correctly matched and undereducated categories here remains the same as under the ASCO-based approach, the increased number of 36 overeducated categories permits a more detailed look at the earnings effects of being overeducated by larger extents. Further comments on this approach, and its benefits, are offered in a subsequent section.

\section{Estimation Models}

The ORU model of earnings can be expressed in the following form:

$$
\log w_{i}=\beta_{1} Z_{i}+\beta_{2} D_{i}^{o}+\beta_{3} D_{i}^{r}+\beta_{4} D_{i}^{u}+\epsilon_{i}
$$


where $w$ represents the hourly wage, used in the analysis in natural logarithmic format, $Z$ represents a vector of characteristics correlated with earnings, and $D^{o}, D^{u}$ and $D^{r}$ are vectors of dummy variables indicating if the individual is overeducated $\left(D^{o}\right)$, undereducated $\left(D^{u}\right)$, or correctly matched to his or her occupation of employment in terms of education $\left(D^{r}\right)$, as identified in the preceding sub-section. The variables included in $Z$ indicate the graduates' gender, English speaking background, residency status, mode of enrolment, further study status, university group, broad field of study, self-employment status, length of employment, industry of employment, sector of employment, year of graduation and labour market experience. Two proxies for experience are used, namely, the age of the graduate and the years of tenure, with both proxies entered into the estimating equation in quadratic form. The summary statistics and descriptions of these variables can be found in Appendix 1.

In order to obtain a greater understanding of the ORU earnings effects, and their impacts on gender wage differences, a Blinder-Oaxaca decomposition, as outlined in equation (2), is used. To accommodate the fact that a number of alternative nondiscriminatory wage structures can be used in this computation, the decomposition here is based on the average of those which use, respectively, the male $\left(\hat{\beta}_{m}\right)$ and female $\left(\hat{\beta}_{f}\right)$ wage structures in this regard. ${ }^{9}$ The analysis will also incorporate Yun's (2005) 'averaging approach' to overcome the measurement issues raised earlier, and draw comparisons between the results of the conventional decomposition method and those from Yun's (2005) approach.

\footnotetext{
${ }^{9}$ See footnote 2 .
} 


\section{Results \\ Incidence of Overeducation by Gender}

A preliminary assessment of the importance of the difference by gender in the incidence of overeducation and undereducation can be gained from Figure 1, which charts, from 1999 to 2009, the proportion of workers who are appropriately trained for their profession. Three comments are offered about Figure 1. First, across all years, an average of 34 per cent of males are appropriately trained for their jobs, while the corresponding figure for females is 38 per cent. Second, as the incidence of undereducation is trivial among the tertiary qualified (it accounts for less than one per cent of the sample), it is readily apparent that the incidence of overeducation is rather high, at around 60 to 65 per cent, and higher for males than it is for females. A higher incidence of overeducation for males than for females is contrary to what is expected, given the changes in the gender mix of university enrolments over the past two decades, as discussed in the introduction. However, this pattern is consistent with the findings of Kler (2005), who also studied the Australian graduate labour market. Third, the degree of education-job match appears to be gradually decreasing, and thus the extent of education-job mismatch increasing, for both males and females. In other words, if education-job mismatch is a problem for the Australian graduate labour market, it is a problem which has been exacerbated in recent times.

[FIGURE 1 about here]

\section{Results from the ORU Model of Eamings}

The results from the estimation of the ORU model of earnings determination are presented in Table 1 . The results from estimation using the full sample are presented in panel (i), while estimates for the separate samples of males and females are presented in panels (ii) 
and (iii), respectively. Note that ORU variables are denoted by the word 'oru' in the first portion of their names. The middle portion indicates the attained qualification, while the end portion denotes the job level. For example, the variable oru_hons_cert is used for graduates who have attained a bachelor's honours degree, and are working in certificate level jobs. All earnings effects are evaluated with reference to the earnings of graduates with a bachelor's pass degree, and who are working in a bachelor's level job.

\section{[TABLE 1 about here]}

Most of the pooled sample results in panel (i) are broadly similar to those reported in similar studies, and attention is drawn to just two findings. First, the estimated gender wage gap is five per cent, and this is much smaller than that traditionally found in the literature, of up to 15 per cent (see Borland, 1999). As discussed above, the graduate labour market will be affected by a 'young age' effect that will decrease the female wage disadvantage, and a 'high level of education' effect that will increase the female wage disadvantage. The modest five per cent wage effect in the pooled sample analysis suggests that the former of these is the more important influence. This is explored in a subsequent section.

Second, there are distinct differences in earnings outcomes according to whether the graduates are correctly matched, undereducated or overeducated, and most of these differences are statistically significant at the one per cent level. Where overeducated, the earnings outcomes vary according to the extent of the overeducation. Relative to the benchmark group of bachelor's pass degree graduates who are working in bachelor's level jobs, the most severe penalty, of 22 per cent, is observed for the overeducated diploma graduates working in certificate level jobs. The highest earning premium, of 20 per cent, is observed for the overeducated doctoral graduates who work in bachelor's pass degree level 
jobs. Thus there is a difference of over 40 percentage points between the earnings of the highest and lowest paid ORU groups. ${ }^{10}$

There are two striking features of these estimated earnings effects associated with overeducation. First, graduate earnings are more closely related to the nature of the job than to the qualification possessed. For example, graduates who work in a certificate level job earn less than the reference group, regardless of the educational level attained. Second, earnings premiums that tend to increase with the level of qualification are observed for graduates in bachelor's pass degree level jobs. In other words, despite the close linkage of earnings to jobs, there remains a payoff to the acquisition of a higher level of qualification. An exception in this regard is associate degree graduates. These patterns are also observed for the estimations obtained for the separate samples of males and females.

The adjusted $\mathrm{R}^{2}$ for the male and female analyses are 0.218 and 0.164 , respectively. The ORU model of earnings, therefore, can be said to have relatively higher power in explaining the earnings of male graduates. This could be due to two reasons. First, the estimated coefficients for the industry of employment variables indicate that employment in certain industries, such as education and mining, have estimated impacts of greater magnitude for males compared to females. Other industry variables, such as for higher education, construction and engineering, have statistical significance for males, but not for females. Second, due to data unavailability the model does not control for marital status or the number of children the graduates have. These characteristics, arguably, would impact on women more, as the household burden generally falls on women more than men.

An F-test was conducted to see if there were gender differences in the estimated coefficients. This yielded an F-statistic of 21.254, indicating that some or all of the estimated coefficients for males and females differ. A comparison of the coefficients of specific

\footnotetext{
${ }^{10}$ Note that while there are sizeable earnings effects associated with being overeducated, the earnings effects for the correctly matched and undereducated graduates are very modest, the largest being just three per cent.
} 
variables for males and females revealed a number where there are statistically significant differences. These are denoted by the ${ }^{\#}$ beside the variable names in the table. For instance, male Information Technology graduates earn 4.1 per cent less than male Management and Commerce graduates (the benchmark group in the estimating equation), while the corresponding coefficient for females is insignificant. Male Agriculture and Environment graduates earn 16.3 per cent less than the benchmark group, while female graduates in this category are slightly better off, with a smaller earnings disadvantage of 10.9 per cent. Similarly, female Nursing graduates earn 9.8 per cent less than the reference category while their male counterparts earn 15.2 per cent less. These differences are reasonably minor, and affect relatively few in the sample, and so the discussion will focus on the gender differences in the ORU earnings effects.

\section{Gender Differences in the ORU Eamings Impacts}

There are a number of differences between males and females with respect to the estimated coefficients on the ORU variables. All of these differences relate to differences in the size of the point estimates, with the sign of the estimated impacts on earnings being consistent for both sexes. The ' $t$ '-tests of differences between males and females on the specific ORU coefficients indicated that only six of the estimated ORU coefficients differed statistically by gender, namely: i) associate degree graduates working in certificate level jobs; ii) bachelor's honours degree graduates working in diploma level jobs; iii) graduate certificate graduates working in bachelor's pass level jobs; iv) masters degree graduates working in certificate level jobs; v) masters degree graduates working in diploma level jobs, and; vi) doctoral graduates working in certificate level jobs. Two general points can be made regarding these six differences. First, the ORU categories involved are heavily concentrated in the diploma and certificate level jobs and, hence, ORU differences by gender can be said to 
be more likely found for those in lower-level jobs. Second, for these six categories, females were worse off than males in only three categories.

The most substantial penalty to being overeducated is for the associate degree graduates who are working in certificate level jobs (oru_ascdeg_cert): Whereas male associate degree graduates in certificate level jobs earn 14.7 per cent less than the benchmark group their female counterparts earn 22 per cent less than the reference category.

Male graduates with a bachelor's honours degree working in diploma level jobs have earnings that do not differ statistically from the benchmark group of correctly matched bachelor's pass degree graduates. Female graduates with the same educational attainment and working in jobs that require a diploma, however, earn 5.3 per cent less than the female benchmark category. In the category of graduates with graduate certificates working in bachelor's pass level jobs, females marginally outperform their male counterparts in earnings. Female graduates in this category earn 12.7 per cent more than the reference group, while male graduates here earn 10 per cent more.

Masters degree graduates working in diploma level jobs (oru_mast_dip) have positive returns to their higher qualifications. However, males in this category have an earnings return of 7.4 per cent whereas females have a more modest return, of 4.1 per cent. Masters graduates working in certificate level jobs (oru_mast_cert) fare much worse than this, with males having earnings 14.3 per cent less than the benchmark group, and females 11 per cent less than the benchmark group.

A considerable gender difference in the magnitude of the ORU earnings impacts is observed for doctoral graduates in certificate level jobs - the most overeducated category. For male graduates, the impact of being overeducated in this instance is statistically insignificant compared to the benchmark group of male bachelor's pass graduates working in matched jobs. Female graduates in this situation, however, get an earnings premium compared to the 
benchmark group of 12.1 per cent for their surplus human capital. Note, however, that female PhD graduates employed in certificate level jobs have earnings around 8 percentage points lower than female $\mathrm{PhD}$ graduates employed in jobs requiring a bachelor's pass degree.

Of the six estimated coefficients with statistically significant differences between males and females, three (oru_gcert_bach, oru_mast_cert and oru_phd_cert) indicated that females were better off compared to males in terms of the earnings effects associated with overeducation, which is contrary to the predictions of the job search hypothesis outlined above. ${ }^{11}$ Clearly, the above comparison of gender differences in the ORU earnings effects gives little support to this interpretation of the labour market. This, however, could be a reflection of the dominance of workers from metropolitan areas in the present analysis, who are not as geographically constrained in their job search. ${ }^{12}$

\section{ORU Analyses Using Gender-Specific Required Levels of Education}

Thus far, the ORU variables have been constructed using the same reference levels of education for males and females. In this section the analyses are undertaken using genderspecific reference levels of education for each occupation. The greater variation across the ORU categories under this approach provides a better basis for using a Blinder-Oaxaca decomposition in the study of the gender earnings gap.

The conventional job classification approach, such as in ASCO, holds that the same educational standard applies for all workers in an occupation. Empirically, however, it often appears that standards differ between males and females. In the 'reverse regression' literature,

\footnotetext{
${ }^{11}$ Note that occupations were not used as regressors in the main estimating equation, as they were used to construct the ORU variables. However, separate regressions were run with 11 occupational groups as controls to estimate the impact of occupational segregation on ORU earnings effects. For males, the negative earnings effects associated with the ORU variables are reduced once occupations are taken account of. On the contrary, females have their earnings disadvantage exacerbated once occupation is controlled for. This suggests that females are able to offset some of the earnings disadvantages associated with overeducation through occupational mobility.

${ }^{12}$ The data set contains information on the residential and employment postcodes of the graduates. However, these were not entered into the estimating equation, as there were missing values for a substantial number of the respondents.
} 
for example, when schooling levels are regressed on income, a typical finding is that to receive similar pay females generally require higher amounts of education (see Goldberger, 1984; Kapsalis, 1982). Kamalich and Polachek (1982), for example, find that females have around 1.2 years more of schooling, compared to males with similar earnings.

To address this issue, the modal qualification for each gender was obtained for each occupation using data from the 2006 Australian Census. There are 17 occupations, out of the total of 103 listed in the data, in which the modal levels of education differed by gender. Among these 17 occupations, in only 3 instances was the modal level of education higher for males than for females. However, despite the generally higher modal levels of education for females, their incidence of educational match remained unchanged from the figure found in the earlier section, at 38 per cent. Males, however, are less 'matched' to their occupations, with a 30 per cent incidence of educational match, four percentage points less than in the preceding section. This is likely to be a consequence of occupational segregation by gender and the lower reference levels of education in the analysis of male graduates.

The results of the estimation of the earnings equation using the gender-specific modal levels of education are presented in Table 2. In this set of analyses the ORU variables have names beginning with cen. As with the ORU variables in the preceding sections, the cen variable names have the attained qualification in the middle portion (cert to phd), and the modal levels of education at the end portion (y10 to bach).

[TABLE 2 about here]

The adjusted $\mathrm{R}^{2}$ for the analysis of the full sample is 0.186 , which is very similar to the earlier analysis reported in Table 1 . The adjusted $\mathrm{R}^{2}$ values for the male and female estimations in panels (ii) and (iii) are 0.215 and 0.162 , respectively. Thus, there is no 
advantage, and perhaps even a slight disadvantage, from using the additional detail available in these alternative measures of required education. At face value, this suggests that the labour market is not overly discerning in this regard. However, the results of the 't'-tests of differences in the estimated earnings coefficients by gender revealed a much larger number of statistically significant earnings effects differences in the Table 2 analyses, as compared to those in Table 1 . These are again denoted by the " beside the variables' names. Out of the 87 variables in the model, estimated coefficients for 41 of them, or almost half, were found to differ statistically by gender. A review of the estimated coefficients in panels (ii) and (iii) reveals that the magnitudes of earnings effects are generally larger for males, and in some cases are statistically significant for males but not for females. This is similar to the pattern evident in Table 1. Looking at fields of study, for example, it is observed that the estimates for the Information Technology and Engineering graduates are statistically significant at the one per cent level for males, but are insignificant for females. Moreover, the estimates on Agriculture and Environment, Nursing, and Creative Arts and Others are larger (in absolute terms) for males.

The analyses disaggregated by gender, and using gender-specific modal levels of qualifications, are associated with greater variability in the ORU earnings impacts between males and females. Thus, using the 't'-tests of difference, 26 of the 39 ORU variables here differ statistically between males and females. This is a larger proportion than that found for the earlier analyses which did not use gender-specific required levels of education, and this is presumably linked to the greater detail used in the construction of the ORU variables in lower-skilled jobs. Second, the magnitude of the earnings differences by gender are substantially larger, compared to those found in the earlier section. For example, males with a diploma, employed in a job with a modal educational level of a Year 10 qualification, earned a substantial 23 per cent less than the benchmark group of their male counterparts with a 
bachelor's pass degree working in a job where the modal qualification is a bachelor's pass degree. ${ }^{13}$ In comparison, females are much worse off if they are in the same situation, with the earnings effect being negative 52 per cent. Earnings effects differences between males and females exceeding ten percentage points are evident in 18 categories, though these are reasonably evenly divided between cases where males are at an earnings advantage and cases where females are at an earnings advantage.

Further, of the 39 ORU earnings coefficients in this section, only 17 exhibited gender differences in earning impacts that are consistent with the job search hypothesis. While this is a larger proportion compared to that found in the previous section (3 out of 23), it still accounts for less than half of the estimated earnings coefficients. Generally, it can be said that the job search hypothesis does not appear to be validated by the findings here for the Australian graduate labour market.

\section{Blinder-Oaxaca Decomposition}

As noted in relation to equation (2), a Blinder-Oaxaca decomposition can be used to provide a better understanding of the reasons why females have a lower mean rate of pay than males. The findings from this decomposition, based on the average of the results obtained when the female and male wage structures are employed as the non-discriminatory norm, are presented in Table 3. In the current data there is a raw gender wage differential of 9.6 percentage points in favour of males. Of this 9.6 percentage points, the Blinder-Oaxaca decomposition revealed that 4.4 percentage points were attributable to the difference in the endowments of the male and female graduates. The remaining 5.1 percentage points, or slightly over half of the wage difference, can be attributed to the difference in

\footnotetext{
${ }^{13}$ This ORU category consists of farm mangers, and production or transport labourers.
} 
coefficients. $^{14,15}$ The ORU variables accounted for a combined, and very small, 0.3 percentage points of the 'endowment' effect. ${ }^{16}$ The majority (32 out of 39) of the estimated endowment effects for the ORU variables were, however, statistically significant at the 10 per cent level or higher.

[TABLE 3 about here]

The negligible combined endowment effect for the ORU variables may seem inconsistent with the findings reported earlier, of males being less likely to be 'matched' to their occupation (30 per cent incidence of education-occupation match compared with 38 per cent for females) and of there being substantial variation in wages across the ORU categories entered into the estimating equation. An examination of the individual endowment effects for the 39 ORU variables shows that these effects are minute, with the largest estimate being only 0.7 percentage points, for the category of graduates with a masters degree working in certificate level jobs. ${ }^{17}$ Moreover, 21 of the ORU estimated coefficients, or around onehalf of the ORU variables, were of negative sign, while the remaining 18 were of positive sign. A negative sign means that the removal of that component would lead to a wider gender wage gap, whereas a positive sign indicates that removal of that component would lessen the gender wage gap, ceteris paribus. Thus, these effects cancel out, with the net result being that the ORU endowment effects do not favour either gender. This finding provides a basis for further evaluation of the job search hypothesis. Specifically, as there does not appear to be a

\footnotetext{
${ }^{14}$ This 'coefficient' effect is also known as the 'unexplained' wage differential, or discrimination, in the gender wage gap literature.

15 A two-fold decomposition is performed here, for simplicity in the discussion of results, as well as compatibility with most studies in the economics literature. Performing a three-fold decomposition reveals that the 'third' interaction component is small, at 2.5 percentage points. The endowment and coefficient effects were 3.2 and 3.9 percentage points, respectively.

${ }^{16}$ For the unexplained 'coefficient' component, ORU effects account for a modest 1.5 percentage points, out of the 5.2 percentage points.

${ }^{17}$ The individual endowment effects are not reported here, but are available on request.
} 
clear wage advantage (detriment) caused by the ORU endowments for males (females), the job search hypothesis is not validated, at least for the Australian graduate labour market. It would be of interest, however, to know if these findings hold after the measurement issues that were highlighted in the literature review section are accounted for. These issues are addressed in the following section.

\section{The Blinder-Oaxaca Decomposition and the 'Averaging Approach'}

As an extension to the Blinder-Oaxaca decomposition analysis from the preceding section, and bearing in mind the measurement issues raised in the literature review section earlier, equation (2) is re-estimated utilising the 'averaging approach' suggested by Yun (2005). Selected results from this decomposition are presented in Table 4. Panels (i) and (ii) presents the results from the previous decomposition discussed in the preceding section, while panels (iii) and (iv) present the results which have incorporated Yun's (2005) 'averaging approach'. Note that as the results of the overall decomposition do not change, they will not be presented here. Instead, the focus will be on the ORU effects and the change in the constant terms.

\section{[TABLE 4 about here]}

The first key observation that can be made is that the value of the intercept term is markedly different. The estimate for the intercept term in the previous decomposition was around 7.9 percentage points, while the corresponding estimate for the current decomposition with deviation contrast coding is 13 percentage points. This suggests that group membership per se is more important in contributing to the gender wage gap than that indicated from the previous decomposition, where the constant term referred to the outcomes for a single 
reference group, namely, the bachelor's degree graduates working in jobs that require the level of qualification that they possess.

Looking at the estimated coefficient effects associated with the ORU variables, however, indicates very modest changes. 31 out of the 40 ORU variables have coefficient effects in the decomposition that are statistically significant at the ten per cent or higher levels, similar to the 32 out of 39 significant ORU coefficient effects reported under the 'single benchmark' approach from the previous section. The sign on the estimated coefficient effects largely remains unchanged - the only exception is for graduates with an honours degree working in certificate level jobs. The endowment effect for these graduates also changed, from being of a negative sign to being positive. The absolute value of the endowment effect, however, remains small, at 0.2 percentage points.

Further, an examination of the endowment effects in the decomposition for the different levels of required education reveals four general (though not universal) patterns. First, there are few significant gender endowment effects in jobs that require a diploma, and the gender endowment effects in jobs that require a bachelor's degree are mixed. As these are job requirements that are closest to the qualifications of the graduate population, this empirical result indicates that similar sorting outcomes for male and female university graduates occur for such jobs.

Second, jobs that require certificate level qualifications have endowment effects that favour more highly qualified males. That is, fewer more highly qualified males than females work in these jobs that attract a wage penalty. When this result is combined with the first feature mentioned above, the implication is that male and female graduates are differentially sorted into jobs that require lower-level qualifications.

Third, jobs that require Year 12 education typically have endowment effects that favour males. As graduates in these jobs are overeducated, and their overeducation status is 
associated with lower wages, this endowment effect in favour of males must arise because females are more likely than males to be in these intermediate level jobs.

Fourth, jobs that require Year 10 education typically have endowment effects that favour females. Applying the reasoning advanced above, this suggests that males are more likely than females to be in these low-skilled jobs.

In the case of the coefficients effect, there are three findings of note. First, the coefficient effects for jobs that require either a diploma or bachelor's pass degree tend to be associated with a negative effect. In other words, this component of the wage decomposition acts to lessen the male wage advantage that would otherwise occur.

Second, the coefficient effects for jobs that require either a certificate or Year 12 schooling tend to be positive. In other words, the overeducation wage effects associated with university graduates working in these jobs tend to favour males, and lead to a widening of their wage advantage.

Third, the low-skilled jobs requiring only Year 10 are typically associated with similar wage effects for males and females, so that the coefficient effects in the wage decomposition for these jobs are usually not statistically significant. Thus, the decomposition indicates that while the overall wage effects are slight, there are interesting patterns in the data that suggest that there are systematic factors impacting the wage determination process when it is examined from the ORU perspective.

A comparison of the overall contribution of ORU earnings effects to the gender wage gap reveals changes of a moderate scale. Recall from the previous section that ORU earnings effects accounted for a total 0.3 percentage point impact on the endowment effect. Further, the unexplained portion of the gender wage gap, or the coefficient effect, attributed to ORU effects was 1.5 percentage points. Under the 'averaging approach', these values are 0.7 and 3.3 percentage points, respectively. The endowment and coefficient effects of the gender 
wage gap attributable to ORU can thus be said to have doubled. In the case of the endowment effects, ORU earnings effects can be said to play a minor role - they still account for only 17 per cent of the overall endowment effect for the model. The coefficient effect of the gender wage gap attributable to ORU, however, is substantial. ORU earnings effects account for roughly two-thirds of the (modest) estimated coefficient effect of five percentage points. Nevertheless, the finding from the previous section, that the 'job-search' hypothesis is not validated in the Australian graduate labour market, is reinforced by the decomposition utilising Yun’s (2005) ‘averaging’ approach, given the small endowment effects associated with ORU.

\section{The Gender Wage Gap and Age}

The Blinder-Oaxaca decomposition indicated a standardised gender wage gap of 5.2 percentage points. This gender wage gap is of similar size to that estimated by the female dummy variable in the ORU models of earnings in the preceding sections. Further, recall that in an earlier section it was noted that the relatively small gender wage gap observed in the present study might be due to the focus on labour market entrants. Thus, the pooled regression will be used in a more detailed examination of the gender wage gap effect by age. Two approaches are considered in this examination. First, the sample was disaggregated by age groups, and equation (3) was estimated separately for each age group. ${ }^{18}$ The results indicated that for graduates aged 35 years and below, the gender wage gap was around 4.5 per cent. Thereafter, the gender wage gap widened considerably. Females aged 36 to 40 years earned 6 per cent less. Those aged 46 to 50 years experienced earnings 8 per cent lower than their male counterparts. Female workers aged more than 56 years old earned 13 per cent less. These estimates were all significant at the one per cent level. As age increases, both males

\footnotetext{
${ }^{18}$ The results for the full model on these analyses by age groups, and the subsequent pooled regression are not presented in this study, but are available on request.
} 
and females enter higher-wage positions, but the female wage disadvantage widens. This provides some support for the 'glass ceiling' found in other studies.

Second, equation (3) was estimated on the full sample, with an interaction term between gender and age (genage $=$ female*age). The inclusion of this term in the model yielded an estimate of -0.013 for female, and an estimate of -0.004 on genage, both significant at the one per cent level. These estimates can be interpreted as follows. The gender wage gap is three per cent when evaluated at 25 years of age. For graduates aged 40 years old, the gender wage gap is much wider, at nine per cent. This increase in the gender wage gap follows through for increasing years of age, and the gap is a substantial 19 per cent for graduates at the (retirement) age of 65 years.

These findings lend support to the thesis that the relatively small gender wage effect among younger workers, and the larger gender wage effect among older workers, is due to the measure of work experience. Mincer and Polachek (1974) for the US, and Rummery (1992) for Australia, show that changing from a measure of potential work experience to a measure of actual work experience can reduce the standardised wage gap by 40 to 70 per cent. ${ }^{19}$ The competing hypothesis, that the small gender wage gap for young graduates is due mainly to minimum wage effects, does not seem credible when the gradual changes in the gender wage gap with age are considered.

\section{Conclusion}

This paper has examined gender differences and educational mismatch in the Australian graduate labour market, using various analyses and perspectives. A number of conclusions can be drawn from this analysis. First, the gender wage gap for the higher

\footnotetext{
${ }^{19}$ In Rummery (1992) the measure of actual experience was constructed as the number of years worked full time plus a third of the years worked part time. All data were collected retrospectively
} 
educated labour market entrants is smaller than that reported in other Australian studies. Analyses of the change in this with age suggest that it is most likely linked to the measure of work experience included in the estimating equation.

Second, the most substantial penalties to being overeducated are found at the lowest job levels. Most ORU earnings effects do not differ statistically between males and females. Greater earnings penalties and gender differences are found when gender-specific and more detailed required levels of education are used from the Census data than when the genderneutral ASCO-based standards are employed. Nevertheless, the absence of evidence in either set of analyses that females incur greater earnings penalties than males from their overeducated status suggests that females' overeducation does not arise due to their more limited job search.

A third finding reinforces that of the second point. Adding broad controls for occupation to the model impacts negatively (positively) on the ORU earnings effects for female (male) graduates. This indicates that females are more mobile across occupations compared to males. Again, this does not support the theorised outcomes under the job search hypothesis.

Fourth, the Blinder-Oaxaca decomposition revealed that ORU effects accounted for only a negligible portion of the gender wage gap. However, the decomposition revealed interesting trends regarding sorting outcomes and ORU earnings effects for males and females. With regard to jobs that require lower education levels, males were more likely than females to be sorted into jobs requiring Year 10 schooling or certificates. At the same time, the coefficient effects in the decomposition indicated that the estimated ORU effects for higher-level jobs that require a diploma or bachelor's degree tend to narrow the gender wage gap. In contrast, the estimated ORU effects for jobs that require a certificate or Year 12 tend to widen the gender wage gap. 
In summary, there is a gender wage gap in the Australian graduate labour market, though this gap is smaller than that found for the aggregate-level Australian labour market. These findings thus favour education as a tool of eliminating discrimination in the labour market. As females are less overeducated than males, despite the larger representation of the former in higher education, there should not be concern that expanding higher education will disadvantage females. This prognosis is reinforced by the finding that the majority of the estimated ORU penalties do not differ statistically between males and females, and the finding that different levels of overeducation of males and females make a minute contribution to the 'endowment effect' in the gender pay gap decomposition. At the same time, however, a word of caution is needed. The gender wage gap is larger for graduates in the older age groups and who are in more advanced stages of their career. This 'glass ceiling' effect appears substantial. However, whether it is a pure 'glass ceiling' effect, or simply a statistical artefact attributable to the use of a poor measure of work experience in the earnings equation, is a moot point. The collection of detailed work histories will be needed if the understanding of this labour market outcome is a priority. 


\section{Appendix 1}

\section{Table A1 - Summary Statistic s and Description of Expla natory Variables}

Variable Mean Std. Dev.

Dependent Variable

Log hourly wage = Hourly wage, expressed in logarithmic format

\section{University Group}

Group of Eight $=$ Go8 university

$0.279 \quad 0.449$

ATN = ATN university

0.190

0.393

IRU = IRU university

0.130

0.336

Other $=$ Other university (omitted category)

0.400

0.490

Personal Characteristic

Female $=$ Female graduates $($ omitted category $=$ Male graduates $)$

Age $=$ Age, expressed in years

Age squared $=$ Age squared, expressed in years

Non-Australian $=$ No Australian residency status $($ omitted category $=$ Australian residency status)

$0.045 \quad 0.208$

\section{Study Characteristics}

Double degree $=$ Double degree qualification (omitted category $=$ No double degree)

Part-time study = Studied on a part-time basis (omitted category = Studied full-time)

Broad field of study

Natural and Physical Sciences

Information Technology

0.050

Engineering

0.054

0.226

Architecture and Building

0.021

0.142

Agriculture and Environment

0.021

0.144

Nursing

0.071

0.258

Medicine

0.100

0.300

Education

0.145

0.353

Society and Culture

0.171

0.376

Creative Arts and Others

0.063

0.242

Management and Commerce (omitted category)

\section{Employment Characteristics}

Self-employed $=$ Self-employed (omitted category $=$ Not self-employed)

Private sector $=$ Employed in private sector (omitted category $=$ Public sector)

Short-term employment $=$ Employment on contracts less than one year, or on a casual basis (omitted category = Long-term employment) 


\section{Appendix 1 (continued)}

Table A1 - Summary Statistics and Description of Explanatory Variables

\begin{tabular}{|c|c|c|}
\hline Variable & Mean & Std. Dev. \\
\hline \multicolumn{3}{|l|}{ Industry of Employment } \\
\hline Accounting & 0.034 & 0.180 \\
\hline Wholesale and retail & 0.078 & 0.268 \\
\hline Accommodation & 0.033 & 0.178 \\
\hline Manufacturing & 0.041 & 0.198 \\
\hline Forestry and mining & 0.011 & 0.105 \\
\hline Legal services & 0.024 & 0.153 \\
\hline Government & 0.092 & 0.289 \\
\hline Education & 0.145 & 0.352 \\
\hline Higher education & 0.063 & 0.243 \\
\hline Health and community services & 0.158 & 0.365 \\
\hline Medicine and dentistry & 0.040 & 0.196 \\
\hline Construction & 0.013 & 0.112 \\
\hline Other services & 0.077 & 0.267 \\
\hline Transport and communication & 0.031 & 0.173 \\
\hline Engineering consulting & 0.021 & 0.143 \\
\hline Financial services (omitted category) & 0.139 & 0.345 \\
\hline \multicolumn{3}{|l|}{ Year of Graduation } \\
\hline 1999 = Graduated in 1999 (omitted category) & 0.075 & 0.264 \\
\hline $2000=$ Graduated in 2000 & 0.078 & 0.268 \\
\hline $2001=$ Graduated in 2001 & 0.065 & 0.247 \\
\hline $2002=$ Graduated in 2002 & 0.069 & 0.253 \\
\hline $2003=$ Graduated in 2003 & 0.085 & 0.279 \\
\hline $2004=$ Graduated in 2004 & 0.095 & 0.294 \\
\hline $2005=$ Graduated in 2005 & 0.098 & 0.297 \\
\hline $2006=$ Graduated in 2006 & 0.089 & 0.284 \\
\hline $2007=$ Graduated in 2007 & 0.109 & 0.311 \\
\hline $2008=$ Graduated in 2008 & 0.116 & 0.321 \\
\hline $2009=$ Graduated in 2009 & 0.120 & 0.325 \\
\hline
\end{tabular}

Note: Values of means in some categories may not sum to unity due to rounding 


\section{References}

Australian Bureau of Statistics (2004), 'Education \& Work: Higher Education Graduates in the Labour Market', [Online], Australian Bureau of Statistics. Available from: http://www.abs.gov.au/AUSSTATS/abs@.nsf/2f762f95845417aeca25706c00834efa/e 1a27d207c960e79ca256e9e00286295!OpenDocument [17 June 2011]

Battu, H., Belfield, C.R. and Sloane, P.J. (2000), 'How Well can We Measure Graduate Over-Education and its Effects', National Institute Economic Review, 171, 82-93

Birnbaum, M.H. (1979), 'Is there Sex Bias in Salaries of Psychologists?', American Psychologist, 34(8), 719-720

Blinder, A.S. (1973), 'Wage Discrimination: Reduced Form and Structural Estimates', The Journal of Human Resources, 8(4), 436-455

Borland, J. (1999), 'The Equal Pay Case - Thirty Years On', Australian Economic Review, 32(3), 265-272

Buchel, F. and Battu, H. (2003), 'The Theory of Differential Overqualification: Does it Work?', Scottish Journal of Political Economy, 50(1), 1-16

Budría, S. (2011), 'Are Educational Mismatches Responsible for the 'Inequality Increasing Effect' of Education?', Social Indicators Research, 102(3), 409-437

Cotton, J. (1988), 'On the Decomposition of Wage Differentials', Review of Economics and Statistics, 70(2), 236-243

Dolton, P.J. and Vignoles, A. (2000), 'The Incidence and Effects of Overeducation in the UK Graduate Labour Market', Economics of Education Review, 19, 179-198

Duncan, G. and Hoffman, S.D. (1981), 'The Incidence and Wage Effects of Overeducation', Economics of Education Review, 1(1), 75-86

Ferber, M.A. and Green, C.A. (1982), 'Traditional or Reverse Sex Discrimination? A Case Study of a Large Public University', Industrial and Labor Relations Review, 35(4), $550-564$

Fortin, N.M. (2008), 'The Gender Wage Gap among Young Adults in the United States: The Importance of Money versus People', The Journal of Human Resources, 43(4), 884918

Frank, R.H. (1978), 'Why Women Earn Less: The Theory and Estimation of Differential Overqualification', The American Economic Review, 68(3), 360-373

Freeman, R. B. (1976), The Overeducated American, Academic Press, New York

Goldberger, A.S. (1984), 'Reverse Regression and Salary Discrimination', The Journal of Human Resources, 19(3), 293-318

Gregory, B. (1999), 'Labour Market Institutions and the Gender Pay Ratio', The Australian Economic Review, 32(3), 273-278

Guthrie, B. and Johnson, T. (1997). Study of non-response to the 1996 Graduate Destination Survey, Department of Employment, Education, Training and Youth Affairs, Canberra, Australia. Available from: $<$ http://www.dest.gov.au/archive/highered/eippubs/eip9710/front.htm\#contents $>\quad[1$ November 2011]

Hartog, J. (2000), 'Over-education and Earnings: Where are We, Where Should We Go?', Economics of Education Review, 19, 131-147

Jones, F.L. (1983), 'On Decomposing the Wage Gap: A Critical Comment on Blinder's Method', The Journal of Human Resources, 18(1), 126-130

Jones, F.L. and Kelley, J. (1984), 'Decomposing Differences between Groups: A Cautionary Note on Measuring Discrimination', Sociological Methods and Research, 12(3), 323343 
Kamalich, R.F. and Polachek, S.W. (1982), 'Discrimination: Fact or Fiction? An Examination Using an Alternative Approach', Southern Economic Journal, 49(2), 450-461

Kapsalis, C. (1982), ‘A New Measure of Wage Discrimination’, Economics Letters, 9, 287293

Kee, H. J. (2006), 'Glass Ceiling or Sticky Floor? Exploring the Australia Gender Pay Gap', The Economic Record, 82(259), 408-427

Kler, P. (2005), 'Graduate Overeducation in Australia: A Comparison of the Mean and Objective Methods', Education Economics, 13(1), 47-72

Le, A.T. and Miller, P.W. (2002), 'The Rising Education Level of Females in Australia', Education Economics, 10(1), 1-24

Leuven, E. and Oosterbeek, H. (2011), 'Overeducation and Mismatch in the Labor Market', Institute for the Study of Labor Discussion Paper No. 5523, Bonn, Germany

McGoldrick, K. and Robst, J. (1996), 'Gender Differences in Overeducation: A Test of the Theory of Differential Overqualification', Economic Behavior and the Family, 86(2), 280-284

McGuinness, S. (2006), 'Overeducation in the Labour Market', Journal of Economic Surveys, 20(3), 387-418

McGuinness, S. and Bennett, J. (2007), 'Overeducation in the Graduate Labour Market: A Quantile Regression Approach’, Economics of Education Review, 26, 521-531

Miller, P.W. (1994), 'Effects on Earnings of the Removal of Direct Discrimination in Minimum Wage Rates: A Validation of the Blinder Decomposition', Labour Economics, 1(3/4), 347-363

Miller, P.W. (2005), 'The Role of Gender among Low-Paid and High-Paid Workers', The Australian Economic Review, 38(4), 405-417

Miller, P. W. (2007), 'Overeducation and Undereducation in Australia', The Australian Economic Review, 40(3), 292-299

Mincer, J. and Polachek, S. (1974), 'Family Investments in Human Capital: Earnings of Women', Journal of Political Economy, 82, 76-108

Neumark, D. (1988), 'Employer's Discriminatory Behavior and the Estimation of Wage Discrimination', The Journal of Human Resources, 23(3), 279-295

Oaxaca, R. (1973), 'Male-Female Wage Differentials in Urban Labor Markets', International Economic Review, 14(3), 693-709

Oaxaca, R. and Ransom, M.R. (1994), 'On Discrimination and the Decomposition of Wage Differentials', The Journal of Econometrics, 61(1), 5-21

Oaxaca, R. and Ransom, M.R. (1999), 'Identification in Detailed Wage Decompositions', Review of Economics and Statistics, 81(1), 154-157

Preston, A.C. (2001), The Structure and Determinants of Wage Relativities: Evidence from Australia, Ashgate, Aldershot

Robst, J. (2007), 'Education, College Major, and Job Match: Gender Differences in Reasons for Mismatch', Education Economics, 15(2), 159-175

Rummery, S. (1992), 'The Contribution of Intermittent Labour Force Participation to the Gender Wage Differential', The Economic Record, 68(202), 351-364

Strategy and Research Policy in Education (2011), The Gender Agenda: Gender Differences in Higher Education. Available from: <http://www.spre.com.au/download/SPREGenderAgenda2011.pdf > [15 May 2012]

The Economist (2011), The Daughter Also Rises. Available from: $<$ http://www.economist.com/node/21526872> [29th August 2011]

Watson, I. (2010), 'Decomposing the Gender Pay Gap in the Australian Managerial Labour Market', Australian Journal of Labour Economics, 13(1), 49-79 
Weichselbaumer, D. and Winter-Ebmer, R.W. (2005), 'A Meta-Analysis of the International Gender Wage Gap’, Journal of Economic Surveys, 19(3), 479-511

Vahey, S.P. (2000), 'The Great Canadian Training Robbery: Evidence on the Returns to Educational Mismatch', Economics of Education Review, 19, 219-227

Voon, D. and Miller, P. W. (2005), 'Undereducation and Overeducation in the Australian Labour Market', The Economic Record, 81(1), 22-33

Yun, M. (2005), 'A Simple Solution to the Identification Problem in Detailed Wage Decompositions', Economic Inquiry, 43(4), 766-772 
Table 1 - OLSEstimates of the ORU Model of Eamings

\begin{tabular}{|c|c|c|c|}
\hline Variable & $\begin{array}{l}\text { Full } \\
\text { (i) }\end{array}$ & $\begin{array}{l}\text { Males } \\
\text { (ii) }\end{array}$ & $\begin{array}{l}\text { Females } \\
\text { (iii) }\end{array}$ \\
\hline Constant & $2.305^{* * *}$ & $2.233^{* * *}$ & $2.274^{* * *}$ \\
\hline & (175.708) & (95.120) & (151.039) \\
\hline Female & $\begin{array}{c}-0.048 * * * \\
(29.159)\end{array}$ & (a) & (a) \\
\hline Age $^{\#}$ & $\begin{array}{c}0.035 * * * \\
(45.334)\end{array}$ & $\begin{array}{l}0.038 * * * \\
(26.984)\end{array}$ & $\begin{array}{c}0.034^{* * *} \\
(38.731)\end{array}$ \\
\hline Age squared/1000 & $\begin{array}{c}-0.397 * * * \\
(36.847)\end{array}$ & $\begin{array}{c}-0.400 * * * \\
(20.527)\end{array}$ & $\begin{array}{c}-0.404 * * * \\
(32.903)\end{array}$ \\
\hline $\mathrm{NESB}^{\#}$ & $\begin{array}{c}-0.039 * * * \\
(17.352)\end{array}$ & $\begin{array}{c}-0.044^{* * *} \\
(13.066)\end{array}$ & $\begin{array}{c}-0.036^{* * *} \\
(11.803)\end{array}$ \\
\hline Non-Australian ${ }^{\#}$ & $\begin{array}{c}-0.202 * * * \\
(33.694)\end{array}$ & $\begin{array}{c}-0.187 * * * \\
(22.988)\end{array}$ & $\begin{array}{c}-0.216^{* * * *} \\
(24.338)\end{array}$ \\
\hline Tenure & $\begin{array}{c}0.015 * * * \\
(30.517)\end{array}$ & $\begin{array}{l}0.016^{* * *} \\
(20.954)\end{array}$ & $\begin{array}{c}0.014 * * * \\
(22.485)\end{array}$ \\
\hline Tenure squared/1000 & $\begin{array}{c}-0.404^{* * * *} \\
(17.551)\end{array}$ & $\begin{array}{c}-0.471^{* * *} \\
(13.555)\end{array}$ & $\begin{array}{c}-0.376^{* * *} \\
(12.443)\end{array}$ \\
\hline Double degree $^{\#}$ & $\begin{array}{c}0.008^{* * *} \\
(3.016)\end{array}$ & $\begin{array}{l}-0.001 \\
(0.218)\end{array}$ & $\begin{array}{c}0.014 * * * \\
(3.939)\end{array}$ \\
\hline Part-time study ${ }^{\#}$ & $\begin{array}{c}0.086^{* * *} \\
(43.574)\end{array}$ & $\begin{array}{l}0.094^{* * *} \\
(30.379)\end{array}$ & $\begin{array}{c}0.081^{* * *} \\
(31.497)\end{array}$ \\
\hline Further Study ${ }^{\#}$ & $\begin{array}{c}0.007 * * * \\
(3.330)\end{array}$ & $\begin{array}{c}0.012 * * * \\
(3.603)\end{array}$ & $\begin{array}{c}0.004 \\
(1.430)\end{array}$ \\
\hline Go8 & $\begin{array}{c}0.026 * * * \\
(13.210)\end{array}$ & $\begin{array}{c}0.030 * * * \\
(9.994)\end{array}$ & $\begin{array}{c}0.024 * * * \\
(9.378)\end{array}$ \\
\hline ATN & $\begin{array}{r}0.031^{* * *} \\
(13.777)\end{array}$ & $\begin{array}{c}0.028 * * * \\
(7.856)\end{array}$ & $\begin{array}{c}0.034 * * * \\
(11.696)\end{array}$ \\
\hline IRU $^{\#}$ & $\begin{array}{l}0.004 * \\
(1.952)\end{array}$ & $\begin{array}{l}-0.007^{*} \\
(1.911)\end{array}$ & $\begin{array}{c}0.011^{* * *} \\
(4.016)\end{array}$ \\
\hline Natural and Physical Sciences & $\begin{array}{c}-0.076 * * * \\
(20.422)\end{array}$ & $\begin{array}{c}-0.084 * * * \\
(15.260)\end{array}$ & $\begin{array}{c}-0.065^{* * *} \\
(12.916)\end{array}$ \\
\hline Information Technology ${ }^{\#}$ & $\begin{array}{c}-0.031^{* * *} \\
(7.643)\end{array}$ & $\begin{array}{c}-0.041^{* * *} \\
(8.234)\end{array}$ & $\begin{array}{l}-0.007 \\
(0.935)\end{array}$ \\
\hline Engineering ${ }^{\#}$ & $\begin{array}{c}-0.008 * * \\
(2.006)\end{array}$ & $\begin{array}{c}-0.011^{* *} \\
(2.456)\end{array}$ & $\begin{array}{c}0.012 \\
(1.413)\end{array}$ \\
\hline Architecture & $\begin{array}{c}-0.098 * * * \\
(17.467)\end{array}$ & $\begin{array}{c}-0.097 * * * \\
(13.191)\end{array}$ & $\begin{array}{c}-0.092 * * * \\
(10.684)\end{array}$ \\
\hline Agriculture and Environment ${ }^{\#}$ & $\begin{array}{c}-0.138 * * * \\
(27.394)\end{array}$ & $\begin{array}{c}-0.163 * * * \\
(22.880)\end{array}$ & $\begin{array}{c}-0.109 * * * \\
(15.294)\end{array}$ \\
\hline Nursing $^{\#}$ & $\begin{array}{c}-0.113 * * * \\
(28.156)\end{array}$ & $\begin{array}{c}-0.152^{* * *} \\
(15.102)\end{array}$ & $\begin{array}{c}-0.098 * * * \\
(21.165)\end{array}$ \\
\hline Medicine $^{\#}$ & $\begin{array}{c}-0.028 * * * \\
(8.149)\end{array}$ & $\begin{array}{c}-0.041^{* * *} \\
(6.753)\end{array}$ & $\begin{array}{c}-0.019 * * * \\
(4.510)\end{array}$ \\
\hline Education $^{\#}$ & $\begin{array}{c}-0.062 * * * \\
(16.597)\end{array}$ & $\begin{array}{c}-0.075^{* * *} \\
(11.803)\end{array}$ & $\begin{array}{c}-0.052 * * * \\
(11.240)\end{array}$ \\
\hline Society and Culture ${ }^{\#}$ & $\begin{array}{c}-0.058 * * * \\
(21.762)\end{array}$ & $\begin{array}{c}-0.065^{* * *} \\
(14.904)\end{array}$ & $\begin{array}{c}-0.048 * * * \\
(14.257)\end{array}$ \\
\hline Creative Arts and Others ${ }^{\#}$ & $\begin{array}{c}-0.117 * * * \\
(28.527)\end{array}$ & $\begin{array}{c}-0.134 * * * \\
(18.337)\end{array}$ & $\begin{array}{c}-0.102^{* * *} \\
(20.204)\end{array}$ \\
\hline Self-employed & $\begin{array}{c}0.015^{* * *} \\
(2.679)\end{array}$ & $\begin{array}{c}0.007 \\
(0.873)\end{array}$ & $\begin{array}{l}0.017 * * \\
(2.043)\end{array}$ \\
\hline Private sector $^{\#}$ & $\begin{array}{c}-0.054 * * * \\
(25.817)\end{array}$ & $\begin{array}{c}-0.058 * * * \\
(15.709)\end{array}$ & $\begin{array}{c}-0.052 * * * \\
(20.118)\end{array}$ \\
\hline Short-term employment & $\begin{array}{c}-0.095 * * * \\
(49.105)\end{array}$ & $\begin{array}{c}-0.099 * * * \\
(29.550)\end{array}$ & $\begin{array}{c}-0.093 * * * \\
(39.125) \\
\end{array}$ \\
\hline
\end{tabular}


Table 1 (c ontinued) - OLS Estima tes of the ORU Model of Ea mings

\begin{tabular}{|c|c|c|c|}
\hline Variables & $\begin{array}{l}\text { Full } \\
\text { (i) }\end{array}$ & $\begin{array}{l}\text { Males } \\
\text { (ii) }\end{array}$ & $\begin{array}{c}\text { Females } \\
\text { (iii) }\end{array}$ \\
\hline oru_dip_cert & $\begin{array}{c}-0.216 * * * \\
(10.674)\end{array}$ & $\begin{array}{c}-0.186 * * * \\
(6.022)\end{array}$ & $\begin{array}{c}-0.234 * * * \\
(8.785)\end{array}$ \\
\hline oru_dip_dip & $\begin{array}{c}-0.018 \\
(1.561)\end{array}$ & $\begin{array}{c}-0.018 \\
(1.158)\end{array}$ & $\begin{array}{l}-0.020 \\
(1.177)\end{array}$ \\
\hline oru_dip_bach & $\begin{array}{c}0.031 * * \\
(2.564)\end{array}$ & $\begin{array}{c}0.019 \\
(1.033)\end{array}$ & $\begin{array}{c}0.036 * * \\
(2.343)\end{array}$ \\
\hline oru_ascdeg_cert ${ }^{\#}$ & $\begin{array}{c}-0.185 * * * \\
(9.440)\end{array}$ & $\begin{array}{c}-0.147 * * * \\
(5.557)\end{array}$ & $\begin{array}{c}-0.220 * * * \\
(7.704)\end{array}$ \\
\hline oru_ascdeg_dip & $\begin{array}{c}-0.068 * * * \\
(6.195)\end{array}$ & $\begin{array}{c}-0.072 * * * \\
(4.961)\end{array}$ & $\begin{array}{c}-0.066 * * * \\
(3.804)\end{array}$ \\
\hline oru_ascdeg_bach & $\begin{array}{l}-0.019 \\
(1.155)\end{array}$ & $\begin{array}{l}-0.016 \\
(0.688)\end{array}$ & $\begin{array}{l}-0.035 \\
(1.471)\end{array}$ \\
\hline oru_bach_cert & $\begin{array}{c}-0.156 * * * \\
(55.637)\end{array}$ & $\begin{array}{c}-0.160 * * * \\
(35.295)\end{array}$ & $\begin{array}{c}-0.150 * * * \\
(42.038)\end{array}$ \\
\hline oru_bach_dip & $\begin{array}{c}-0.092 * * * \\
(27.292)\end{array}$ & $\begin{array}{c}-0.088^{* * *} \\
(17.170)\end{array}$ & $\begin{array}{c}-0.093 * * * \\
(20.650)\end{array}$ \\
\hline oru_hons_cert & $\begin{array}{c}-0.101 * * * \\
(14.606)\end{array}$ & $\begin{array}{c}-0.096 * * * \\
(9.065)\end{array}$ & $\begin{array}{c}-0.103 * * * \\
(11.428)\end{array}$ \\
\hline oru_hons_dip ${ }^{\#}$ & $\begin{array}{c}-0.037 * * * \\
(4.350)\end{array}$ & $\begin{array}{c}-0.012 \\
(0.971)\end{array}$ & $\begin{array}{c}-0.053 * * * \\
(4.721)\end{array}$ \\
\hline oru_hons_bach & $\begin{array}{c}0.027 * * * \\
(7.719)\end{array}$ & $\begin{array}{c}0.030 * * * \\
(6.037)\end{array}$ & $\begin{array}{c}0.029 * * * \\
(5.719)\end{array}$ \\
\hline oru_gcert_cert & $\begin{array}{c}-0.082 * * * \\
(7.423)\end{array}$ & $\begin{array}{c}-0.072 * * * \\
(4.913)\end{array}$ & $\begin{array}{c}-0.094 * * * \\
(5.994)\end{array}$ \\
\hline oru_gcert_dip & $\begin{array}{c}0.015 \\
(1.563)\end{array}$ & $\begin{array}{c}0.009 \\
(0.674)\end{array}$ & $\begin{array}{c}0.012 \\
(0.807)\end{array}$ \\
\hline oru_gcert_bach ${ }^{\#}$ & $\begin{array}{c}0.118 * * * \\
(32.361)\end{array}$ & $\begin{array}{c}0.100 * * * \\
(16.294)\end{array}$ & $\begin{array}{c}0.127^{* * *} \\
(28.118)\end{array}$ \\
\hline oru_gdip_cert & $\begin{array}{c}-0.117 * * * \\
(12.961)\end{array}$ & $\begin{array}{c}-0.130 * * * \\
(9.141)\end{array}$ & $\begin{array}{c}-0.110 * * * \\
(9.513)\end{array}$ \\
\hline oru_gdip_dip & $\begin{array}{l}-0.008 \\
(0.901)\end{array}$ & $\begin{array}{l}-0.009 \\
(0.672)\end{array}$ & $\begin{array}{l}-0.015 \\
(1.281)\end{array}$ \\
\hline oru_gdip_bach & $\begin{array}{c}0.089 * * * \\
(31.084)\end{array}$ & $\begin{array}{c}0.093 * * * \\
(18.749)\end{array}$ & $\begin{array}{c}0.085 * * * \\
(24.412)\end{array}$ \\
\hline oru_mast_cert ${ }^{\#}$ & $\begin{array}{c}-0.122 * * * \\
(14.613)\end{array}$ & $\begin{array}{c}-0.143 * * * \\
(12.174)\end{array}$ & $\begin{array}{c}-0.109 * * * \\
(9.097)\end{array}$ \\
\hline oru_mast_dip ${ }^{\#}$ & $\begin{array}{c}0.066^{* * *} \\
(8.391)\end{array}$ & $\begin{array}{c}0.074 * * * \\
(7.129)\end{array}$ & $\begin{array}{c}0.041^{* * *} \\
(3.518)\end{array}$ \\
\hline oru_mast_bach & $\begin{array}{l}0.183 * * * \\
(63.714)\end{array}$ & $\begin{array}{l}0.186 * * * \\
(41.567)\end{array}$ & $\begin{array}{c}0.174 * * * \\
(45.974)\end{array}$ \\
\hline oru_phd_cert ${ }^{\#}$ & $\begin{array}{c}0.076^{* * *} \\
(3.249)\end{array}$ & $\begin{array}{c}0.010 \\
(0.289)\end{array}$ & $\begin{array}{c}0.121^{* * *} \\
(3.803)\end{array}$ \\
\hline oru_phd_dip & $\begin{array}{c}0.084 * * * \\
(4.066)\end{array}$ & $\begin{array}{c}0.078 * * * \\
(2.698)\end{array}$ & $\begin{array}{c}0.089 * * * \\
(2.995)\end{array}$ \\
\hline oru_phd_bach & $\begin{array}{c}0.199 * * * \\
(39.303)\end{array}$ & $\begin{array}{c}0.192 * * * \\
(26.622)\end{array}$ & $\begin{array}{c}0.197 * * * \\
(27.509)\end{array}$ \\
\hline $\begin{array}{l}\text { Industry } \\
\text { Year of Graduation }\end{array}$ & $\begin{array}{l}\text { Included } \\
\text { Included }\end{array}$ & $\begin{array}{l}\text { Included } \\
\text { Included }\end{array}$ & $\begin{array}{l}\text { Included } \\
\text { Included }\end{array}$ \\
\hline Observations & 569,325 & 221,746 & 347,579 \\
\hline Adjusted $\mathrm{R}^{2}$ & 0.188 & 0.218 & 0.164 \\
\hline F-statistic & 1720.73 & 804.87 & 928.1 \\
\hline
\end{tabular}


Table 2 - OLS Estimates of the ORU Model, Gender-specific Required Education

\begin{tabular}{|c|c|c|c|}
\hline Variable & $\begin{array}{l}\text { Full } \\
\text { (i) }\end{array}$ & $\begin{array}{l}\text { Male } \\
\text { (ii) }\end{array}$ & $\begin{array}{l}\text { Female } \\
\text { (iii) }\end{array}$ \\
\hline Constant & $\begin{array}{l}2.228 * * * \\
(171.798)\end{array}$ & $\begin{array}{l}2.120^{* * *} \\
(91.246)\end{array}$ & $\begin{array}{l}2.199 * * * \\
(148.410)\end{array}$ \\
\hline Female & $\begin{array}{c}-0.049 * * * \\
(-29.650)\end{array}$ & (a) & (a) \\
\hline Age $^{\#}$ & $\begin{array}{c}0.041^{* * *} \\
(53.392)\end{array}$ & $\begin{array}{c}0.044 * * * \\
(32.029)\end{array}$ & $\begin{array}{c}0.040 * * * \\
(45.767)\end{array}$ \\
\hline Age squared/1000 & $\begin{array}{c}-0.455 * * * \\
(-42.603)\end{array}$ & $\begin{array}{c}-0.466 * * * \\
(-24.032)\end{array}$ & $\begin{array}{c}-0.461 * * * \\
(-37.899)\end{array}$ \\
\hline Tenure $^{\#}$ & $\begin{array}{c}0.019 * * * \\
(39.528)\end{array}$ & $\begin{array}{c}0.019 * * * \\
(25.898)\end{array}$ & $\begin{array}{c}0.017 * * * \\
(28.936)\end{array}$ \\
\hline Tenure squared $/ 1000^{\#}$ & $\begin{array}{c}-0.538 * * * \\
(-23.251)\end{array}$ & $\begin{array}{c}-0.609 * * * \\
(-17.259)\end{array}$ & $\begin{array}{c}-0.502^{* * * *} \\
(-16.594)\end{array}$ \\
\hline NESB $^{\#}$ & $\begin{array}{c}-0.044 * * * \\
(-19.578)\end{array}$ & $\begin{array}{c}-0.050 * * * \\
(-14.648)\end{array}$ & $\begin{array}{c}-0.040 * * * \\
(-13.149)\end{array}$ \\
\hline Non-Australian & $\begin{array}{c}-0.214 * * * \\
(-35.822)\end{array}$ & $\begin{array}{c}-0.213^{* * *} \\
(-26.568)\end{array}$ & $\begin{array}{c}-0.227 * * * \\
(-25.612)\end{array}$ \\
\hline Further study ${ }^{\#}$ & $\begin{array}{c}0.006^{* * * *} \\
(2.832)\end{array}$ & $\begin{array}{c}0.010 * * * \\
(3.034)\end{array}$ & $\begin{array}{c}0.003 \\
(0.895)\end{array}$ \\
\hline $\mathrm{Go}^{\#}$ & $\begin{array}{c}0.021 * * * \\
(11.219)\end{array}$ & $\begin{array}{c}0.030 * * * \\
(9.954)\end{array}$ & $\begin{array}{c}0.021 * * * \\
(8.350)\end{array}$ \\
\hline ATN & $\begin{array}{c}0.030 * * * \\
(13.278)\end{array}$ & $\begin{array}{c}0.032 * * * \\
(9.041)\end{array}$ & $\begin{array}{c}0.033 * * * \\
(11.519)\end{array}$ \\
\hline $\mathrm{IRU}^{\#}$ & $\begin{array}{c}-0.000 \\
(-0.148)\end{array}$ & $\begin{array}{c}-0.011 * * * \\
(-2.943)\end{array}$ & $\begin{array}{c}0.008^{* * *} \\
(2.754)\end{array}$ \\
\hline Natural and Physical Sciences & $\begin{array}{c}-0.090 * * * \\
(-24.251)\end{array}$ & $\begin{array}{c}-0.085^{* * *} \\
(-15.413)\end{array}$ & $\begin{array}{r}-0.082 * * * \\
(-16.351)\end{array}$ \\
\hline Information Technology $^{\#}$ & $\begin{array}{c}-0.033 * * * \\
(-8.136)\end{array}$ & $\begin{array}{c}-0.032 * * * \\
(-6.436)\end{array}$ & $\begin{array}{l}-0.012 \\
(-1.585)\end{array}$ \\
\hline Engineering & $\begin{array}{c}-0.021 * * * \\
(-5.394)\end{array}$ & $\begin{array}{c}-0.013 * * * \\
(-2.670)\end{array}$ & $\begin{array}{c}0.002 \\
(0.223)\end{array}$ \\
\hline Architecture & $\begin{array}{c}-0.116 * * * \\
(-20.724)\end{array}$ & $\begin{array}{c}-0.095^{* * *} \\
(-12.870)\end{array}$ & $\begin{array}{c}-0.110 * * * \\
(-12.745)\end{array}$ \\
\hline Agriculture and Environment ${ }^{\#}$ & $\begin{array}{c}-0.137 * * * \\
(-27.158)\end{array}$ & $\begin{array}{c}-0.158 * * * \\
(-22.057)\end{array}$ & $\begin{array}{r}-0.113 * * * \\
(-15.675)\end{array}$ \\
\hline Nursing ${ }^{\#}$ & $\begin{array}{c}-0.124 * * * \\
(-30.761)\end{array}$ & $\begin{array}{c}-0.155^{* * * *} \\
(-15.201)\end{array}$ & $\begin{array}{c}-0.113 * * * \\
(-24.178)\end{array}$ \\
\hline Medicine & $\begin{array}{c}-0.038 * * * \\
(-11.018)\end{array}$ & $\begin{array}{c}-0.042 * * * \\
(-6.886)\end{array}$ & $\begin{array}{c}-0.032 * * * \\
(-7.479)\end{array}$ \\
\hline Education $^{\#}$ & $\begin{array}{c}-0.070 * * * \\
(-18.962)\end{array}$ & $\begin{array}{c}-0.076^{* * * *} \\
(-11.950)\end{array}$ & $\begin{array}{r}-0.060 * * * \\
(-13.056)\end{array}$ \\
\hline Society and Culture ${ }^{\#}$ & $\begin{array}{c}-0.060 * * * \\
(-22.313)\end{array}$ & $\begin{array}{c}-0.064 * * * \\
(-14.735)\end{array}$ & $\begin{array}{r}-0.049 * * * \\
(-14.487)\end{array}$ \\
\hline Creative Arts and Others ${ }^{\#}$ & $\begin{array}{c}-0.126 * * * \\
(-30.672)\end{array}$ & $\begin{array}{c}-0.137 * * * \\
(-18.820)\end{array}$ & $\begin{array}{c}-0.109 * * * \\
(-21.485)\end{array}$ \\
\hline Self-employed & $\begin{array}{c}0.019 * * * \\
(3.285)\end{array}$ & $\begin{array}{l}0.014^{*} \\
(1.720)\end{array}$ & $\begin{array}{l}0.018^{* *} \\
(2.215)\end{array}$ \\
\hline Private sector & $\begin{array}{c}-0.054 * * * \\
(-25.374)\end{array}$ & $\begin{array}{c}-0.056^{* * *} \\
(-15.084)\end{array}$ & $\begin{array}{r}-0.050 * * * \\
(-19.336)\end{array}$ \\
\hline Short-term employment ${ }^{\#}$ & $\begin{array}{c}-0.101 * * * \\
(-52.295)\end{array}$ & $\begin{array}{c}-0.110^{* * *} \\
(-32.906)\end{array}$ & $\begin{array}{r}-0.098 * * * \\
(-41.398)\end{array}$ \\
\hline$c e n \_d i p \_y 10^{\#}$ & $\begin{array}{c}-0.374 * * * \\
(-6.841)\end{array}$ & $\begin{array}{c}-0.228 * * * \\
(-3.438)\end{array}$ & $\begin{array}{c}-0.523 * * * \\
(-3.761)\end{array}$ \\
\hline cen_dip_y12 & $\begin{array}{c}-0.148 * * * \\
(-7.326)\end{array}$ & $\begin{array}{c}-0.122 * * \\
(-2.453)\end{array}$ & $\begin{array}{c}-0.172 * * * \\
(-7.221)\end{array}$ \\
\hline cen_dip_cert ${ }^{\#}$ & $\begin{array}{c}-0.016 \\
(-1.394)\end{array}$ & $\begin{array}{c}0.013 \\
(0.993)\end{array}$ & $\begin{array}{c}-0.109 * * * \\
(-3.334)\end{array}$ \\
\hline
\end{tabular}




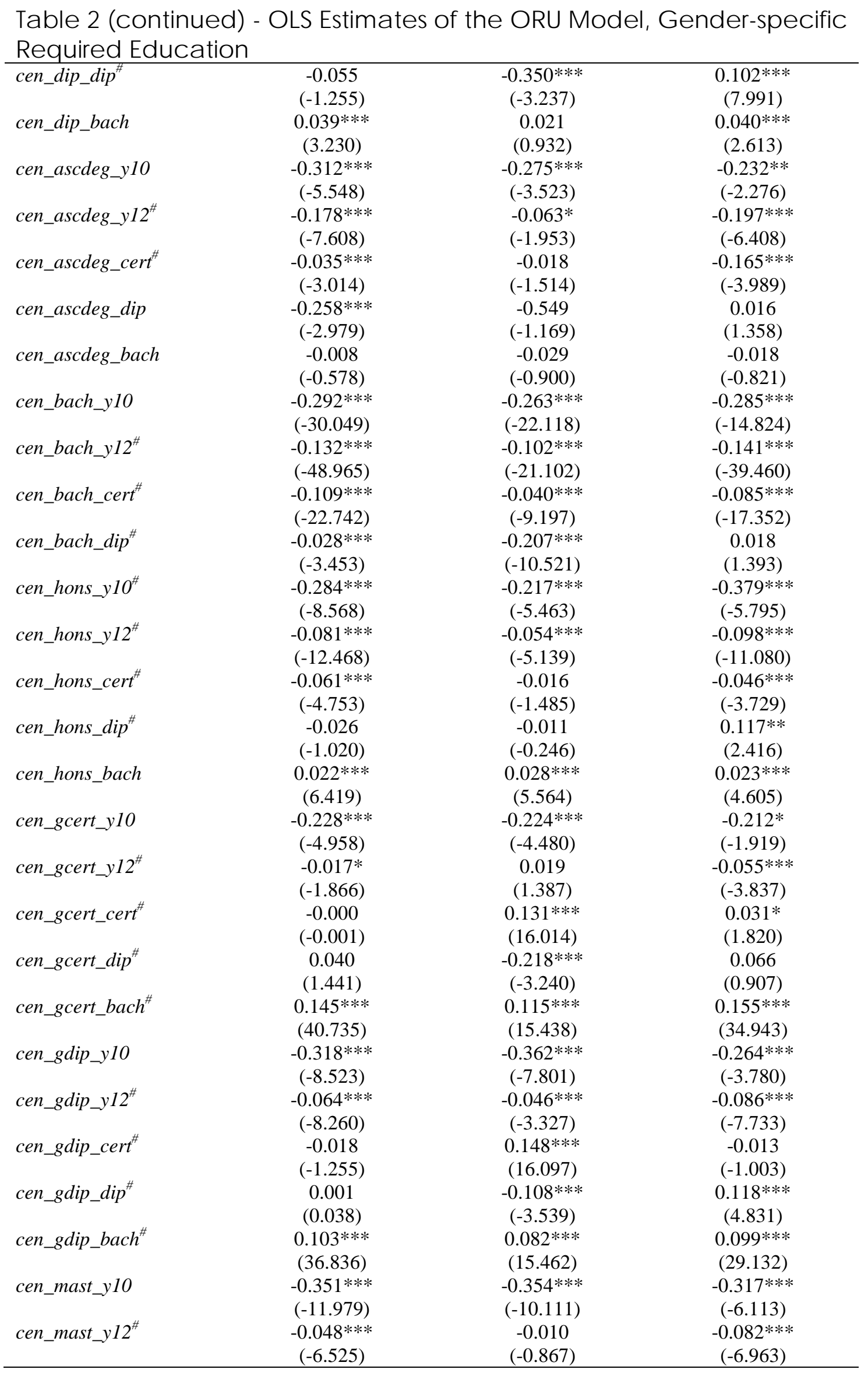




\begin{tabular}{|c|c|c|c|}
\hline & $0.055^{* * *}$ & $0.238 * * *$ & $0.065^{* * *}$ \\
\hline & $(4.732)$ & (38.381) & $(5.670)$ \\
\hline cen_mast_dip ${ }^{\#}$ & $\begin{array}{c}0.088^{* * *} \\
(4.820)\end{array}$ & $\begin{array}{c}-0.140 * * * \\
(-3.711)\end{array}$ & $\begin{array}{l}0.060^{*} \\
(1955)\end{array}$ \\
\hline cen_mast_bach ${ }^{\#}$ & $\begin{array}{l}0.201 * * * \\
(71.672)\end{array}$ & $\begin{array}{c}0.163^{* * *} \\
(32.360)\end{array}$ & $\begin{array}{r}0.191 * * * \\
(51.265)\end{array}$ \\
\hline cen_phd_y10 & $\begin{array}{l}-0.256^{*} \\
(-1.823)\end{array}$ & $\begin{array}{c}-0.283 * * * \\
(-2.956)\end{array}$ & $\begin{array}{c}-0.370 \\
(-0.933)\end{array}$ \\
\hline cen_phd_y12 & $\begin{array}{c}0.107 * * * \\
(6.304)\end{array}$ & $\begin{array}{c}0.077 * * \\
(2.365)\end{array}$ & $\begin{array}{c}0.132 * * * \\
(5.198)\end{array}$ \\
\hline cen_phd_cert ${ }^{\#}$ & $\begin{array}{c}0.096 * * \\
(2.430)\end{array}$ & $\begin{array}{c}0.228^{* * *} \\
(13.918)\end{array}$ & $\begin{array}{c}0.145^{* * *} \\
(6.343)\end{array}$ \\
\hline cen_phd_dip & $\begin{array}{c}0.188 * * * \\
(4.476)\end{array}$ & $\begin{array}{c}-0.020 \\
(-0.169)\end{array}$ & $\begin{array}{c}0.534 \\
(1.066)\end{array}$ \\
\hline cen_phd_bach ${ }^{\#}$ & $\begin{array}{c}0.192 * * * \\
(38.078)\end{array}$ & $\begin{array}{c}0.172^{* * *} \\
(22.609)\end{array}$ & $\begin{array}{c}0.190 * * * \\
(26.514)\end{array}$ \\
\hline $\begin{array}{l}\text { Observations } \\
\text { Adiusted } \mathrm{R}^{2}\end{array}$ & $\begin{array}{c}569,325 \\
0186\end{array}$ & $\begin{array}{c}221,746 \\
0215\end{array}$ & $\begin{array}{c}347,579 \\
0162\end{array}$ \\
\hline
\end{tabular}

Notes: Absolute values of heteroscedasticity consistent ' $t$ '-statistics are presented in parentheses. *, ** and *** indicate significance at the ten, five and one per cent levels, respectively. The models included dummy variables for 15 industries of employment, and for the 10 years of graduation. * indicates significance for the t-test of difference. (a) indicates that the variable was not entered in the estimating equation. 
Table 3 - Estimates from the Blinder-Oaxaca Decomposition

Predicted Male Wage 3.0658***

(0.0013)

Predicted Female Wage $\quad 2.9701^{* * *}$

Raw Wage Gap $\quad 0.0957^{* * *}$

(0.0017)

Explained

$0.0443^{* * *}$

$(0.0012)$

Unexplained

$0.0514 * * *$

Constant

$(0.0018)$

$-0.0788^{* * *}$

$(0.0221)$

Observations

569,325

Note: Standard errors are presented in parentheses. ***, ** and * denote

significance at the one, five and ten per cent levels, respectively. 
Table 4 - Selected Results from the Blinder-Oaxaca Decomposition and Deviation Contrast Coding

\begin{tabular}{|c|c|c|c|c|}
\hline \multirow[b]{2}{*}{ Variable } & \multicolumn{2}{|c|}{ Single Benchmark } & \multicolumn{2}{|c|}{ Deviation Contrast Coding } \\
\hline & $\begin{array}{l}\text { Explained } \\
\text { (i) }\end{array}$ & $\begin{array}{l}\text { Unexplained } \\
\text { (ii) }\end{array}$ & $\begin{array}{l}\text { Explained } \\
\text { (iii) }\end{array}$ & $\begin{array}{l}\text { Unexplained } \\
\text { (iv) }\end{array}$ \\
\hline cen_bach_bach & & & $\begin{array}{l}-0.0042^{* * *} \\
(0.0005)\end{array}$ & $\begin{array}{l}0.0098 * * \\
(0.0045)\end{array}$ \\
\hline cen_dip_y10 & $\begin{array}{l}-0.0001^{* * *} \\
(0.0000)\end{array}$ & $\begin{array}{l}0.0001 * * * \\
(0.0000)\end{array}$ & $\begin{array}{l}-0.0001^{* * *} \\
(0.0000)\end{array}$ & $\begin{array}{l}0.0001 * * * \\
(0.0000)\end{array}$ \\
\hline cen_dip_y12 & $\begin{array}{l}0.0001 * * * \\
(0.0000)\end{array}$ & $\begin{array}{l}0.0001 \\
(0.0001)\end{array}$ & $\begin{array}{l}0.0000 * * * \\
(0.0000)\end{array}$ & $\begin{array}{l}0.0001 * \\
(0.0001)\end{array}$ \\
\hline cen_dip_cert & $\begin{array}{l}-0.0002^{* *} \\
(0.0001)\end{array}$ & $\begin{array}{l}0.0003 * * * \\
(0.0001)\end{array}$ & $\begin{array}{l}0.0000 \\
(0.0001)\end{array}$ & $\begin{array}{l}0.0004 * * * \\
(0.0001)\end{array}$ \\
\hline cen_dip_dip & $\begin{array}{l}0.0001 * * \\
(0.0000)\end{array}$ & $\begin{array}{l}-0.0002^{* * *} \\
(0.0000)\end{array}$ & $\begin{array}{l}0.0000 \\
(0.0000)\end{array}$ & $\begin{array}{l}-0.0002^{* * * *} \\
(0.0000)\end{array}$ \\
\hline cen_dip_bach & $\begin{array}{l}0.0000 \\
(0.0000)\end{array}$ & $\begin{array}{l}-0.0000 \\
(0.0001)\end{array}$ & $\begin{array}{l}0.0000 \\
(0.0000)\end{array}$ & $\begin{array}{l}0.0000 \\
(0.0001)\end{array}$ \\
\hline cen_ascdeg_y10 & $\begin{array}{l}-0.0001^{* * *} \\
(0.0000)\end{array}$ & $\begin{array}{l}-0.0000 \\
(0.0000)\end{array}$ & $\begin{array}{l}-0.0000 * * \\
(0.0000)\end{array}$ & $\begin{array}{l}-0.0000 \\
(0.0000)\end{array}$ \\
\hline cen_ascdeg_y12 & $\begin{array}{l}0.0001 * * * \\
(0.0000)\end{array}$ & $\begin{array}{l}0.0001^{* *} \\
(0.0000)\end{array}$ & $\begin{array}{l}0.0000^{* *} \\
(0.0000)\end{array}$ & $\begin{array}{l}0.0001 * * * \\
(0.0000)\end{array}$ \\
\hline cen_ascdeg_cert & $\begin{array}{l}-0.0005^{* * *} \\
(0.0001)\end{array}$ & $\begin{array}{l}0.0005 * * * \\
(0.0001)\end{array}$ & $\begin{array}{l}-0.0002 * \\
(0.0001)\end{array}$ & $\begin{array}{l}0.0006 * * * \\
(0.0001)\end{array}$ \\
\hline cen_ascdeg_dip & $\begin{array}{l}0.0003 * * * \\
(0.0001)\end{array}$ & $\begin{array}{l}-0.0003^{* * *} \\
(0.0001)\end{array}$ & $\begin{array}{l}0.0002 * * * \\
(0.0001)\end{array}$ & $\begin{array}{l}-0.0003^{* * *} \\
(0.0001)\end{array}$ \\
\hline cen_ascdeg_bach & $\begin{array}{l}-0.0000 \\
(0.0000)\end{array}$ & $\begin{array}{l}-0.0000 \\
(0.0001)\end{array}$ & $\begin{array}{l}0.0000 \\
(0.0000)\end{array}$ & $\begin{array}{l}0.0000 \\
(0.0001)\end{array}$ \\
\hline cen_bach_y10 & $\begin{array}{l}-0.0040^{* * *} \\
(0.0001)\end{array}$ & $\begin{array}{l}0.0003 \\
(0.0002)\end{array}$ & $\begin{array}{l}-0.0032^{* * *} \\
(0.0002)\end{array}$ & $\begin{array}{l}0.0006^{* *} \\
(0.0003)\end{array}$ \\
\hline cen_bach_y12 & $\begin{array}{l}0.0084 * * * \\
(0.0002)\end{array}$ & $\begin{array}{l}0.0049 * * * \\
(0.0008)\end{array}$ & $\begin{array}{l}0.0044^{* * * *} \\
(0.0005)\end{array}$ & $\begin{array}{l}0.0086 * * * \\
(0.0017)\end{array}$ \\
\hline cen_bach_cert & $\begin{array}{l}-0.0040^{* * *} \\
(0.0002)\end{array}$ & $\begin{array}{l}0.0038 * * * \\
(0.0005)\end{array}$ & $\begin{array}{l}-0.0003 \\
(0.0004)\end{array}$ & $\begin{array}{l}0.0062 * * * \\
(0.0012)\end{array}$ \\
\hline cen_bach_dip & $\begin{array}{l}-0.0006^{* * *} \\
(0.0001)\end{array}$ & $\begin{array}{l}-0.0013^{* * *} \\
(0.0001)\end{array}$ & $\begin{array}{l}-0.0002^{* * *} \\
(0.0001)\end{array}$ & $\begin{array}{l}-0.0011^{* * *} \\
(0.0002)\end{array}$ \\
\hline cen_hons_y10 & $\begin{array}{l}-0.0003^{* * *} \\
(0.0000)\end{array}$ & $\begin{array}{l}0.0002 * * * \\
(0.0001)\end{array}$ & $\begin{array}{l}-0.0003^{* * *} \\
(0.0000)\end{array}$ & $\begin{array}{l}0.0002 * * * \\
(0.0001)\end{array}$ \\
\hline cen_hons_y12 & $\begin{array}{l}0.0005 * * * \\
(0.0001)\end{array}$ & $\begin{array}{l}0.0006 * * * \\
(0.0002)\end{array}$ & $\begin{array}{l}0.0001 * \\
(0.0001)\end{array}$ & $\begin{array}{l}0.0009 * * * \\
(0.0002)\end{array}$ \\
\hline cen_hons_cert & $\begin{array}{l}-0.0002^{* * *} \\
(0.0001)\end{array}$ & $\begin{array}{l}0.0003 * \\
(0.0002)\end{array}$ & $\begin{array}{l}0.0002 * * \\
(0.0001)\end{array}$ & $\begin{array}{l}0.0005 * * * \\
(0.0002)\end{array}$ \\
\hline cen_hons_dip & $\begin{array}{l}0.0000 \\
(0.0000)\end{array}$ & $\begin{array}{l}-0.0001 \\
(0.0000)\end{array}$ & $\begin{array}{l}0.0001^{* *} \\
(0.0000)\end{array}$ & $\begin{array}{l}-0.0000 \\
(0.0000)\end{array}$ \\
\hline cen_hons_bach & $\begin{array}{l}0.0002 * * * \\
(0.0000)\end{array}$ & $\begin{array}{l}0.0003 \\
(0.0004)\end{array}$ & $\begin{array}{l}0.0008^{* * *} \\
(0.0001)\end{array}$ & $\begin{array}{l}0.0016^{* *} \\
(0.0007)\end{array}$ \\
\hline cen_gcert_y10 & $\begin{array}{l}-0.0001^{* * *} \\
(0.0000)\end{array}$ & $\begin{array}{l}-0.0000 \\
(0.0000)\end{array}$ & $\begin{array}{l}-0.0001^{* * *} \\
(0.0000)\end{array}$ & $\begin{array}{l}0.0000 \\
(0.0000)\end{array}$ \\
\hline cen_gcert_y12 & $\begin{array}{l}-0.0000 \\
(0.0000)\end{array}$ & $\begin{array}{l}0.0005 * * * \\
(0.0001)\end{array}$ & $\begin{array}{l}0.0000 * \\
(0.0000)\end{array}$ & $\begin{array}{l}0.0006 * * * \\
(0.0001)\end{array}$ \\
\hline cen_gcert_cert & $\begin{array}{l}0.0014 * * * \\
(0.0001)\end{array}$ & $\begin{array}{l}0.0013 * * * \\
(0.0002)\end{array}$ & $\begin{array}{l}0.0023 * * * \\
(0.0002)\end{array}$ & $\begin{array}{l}0.0016 * * * \\
(0.0003)\end{array}$ \\
\hline cen_gcert_dip & $\begin{array}{l}-0.0000^{*} \\
(0.0000)\end{array}$ & $\begin{array}{l}-0.0001^{* * *} \\
(0.0000)\end{array}$ & $\begin{array}{l}-0.0000 \\
(0.0000)\end{array}$ & $\begin{array}{l}-0.0001 * * * \\
(0.0000)\end{array}$ \\
\hline cen_gcert_bach & $\begin{array}{l}-0.0027^{* * *} \\
(0.0001)\end{array}$ & $\begin{array}{l}-0.0015^{* * * *} \\
(0.0003)\end{array}$ & $\begin{array}{l}-0.0039 * * * \\
(0.0002)\end{array}$ & $\begin{array}{l}-0.0004 \\
(0.0006)\end{array}$ \\
\hline cen_gdip_y10 & $\begin{array}{l}-0.0003^{* * *} \\
(0.0000)\end{array}$ & $\begin{array}{l}-0.0001 * \\
(0.0000)\end{array}$ & $\begin{array}{l}-0.0002^{* * *} \\
(0.0000)\end{array}$ & $\begin{array}{l}-0.0001 \\
(0.0000)\end{array}$ \\
\hline cen_gdip_y12 & $\begin{array}{l}0.0002 * * * \\
(0.0000)\end{array}$ & $\begin{array}{l}0.0004^{* *} \\
(0.0002)\end{array}$ & $\begin{array}{l}0.0000 \\
(0.0000)\end{array}$ & $\begin{array}{l}0.0006 * * * \\
(0.0002)\end{array}$ \\
\hline
\end{tabular}


Table 4 (continued) - Selected Results from the Blinder-Oaxaca Decomposition and Deviation Contrast Coding

\begin{tabular}{|c|c|c|c|c|}
\hline Variable & $\begin{array}{l}\text { Explained } \\
\text { (i) }\end{array}$ & $\begin{array}{l}\text { Unexplained } \\
\text { (ii) }\end{array}$ & $\begin{array}{l}\text { Explained } \\
\text { (iii) }\end{array}$ & $\begin{array}{l}\text { Unexplained } \\
\text { (iv) }\end{array}$ \\
\hline cen_gdip_cert & $\begin{array}{l}0.0009 * * * \\
(0.0001)\end{array}$ & $\begin{array}{l}0.0021 * * * \\
(0.0002)\end{array}$ & $\begin{array}{l}0.0016 * * * \\
(0.0001)\end{array}$ & $\begin{array}{l}0.0025^{* * *} \\
(0.0003)\end{array}$ \\
\hline cen_gdip_dip & $\begin{array}{l}0.0000 \\
(0.0000)\end{array}$ & $\begin{array}{l}-0.0001^{* * *} \\
(0.0000)\end{array}$ & $\begin{array}{l}0.0000 * \\
(0.0000)\end{array}$ & $\begin{array}{l}-0.0001 * * * \\
(0.0000)\end{array}$ \\
\hline cen_gdip_bach & $\begin{array}{l}-0.0030^{* * *} \\
(0.0001)\end{array}$ & $\begin{array}{l}-0.0012^{* *} \\
(0.0005)\end{array}$ & $\begin{array}{l}-0.0049 * * * \\
(0.0003)\end{array}$ & $\begin{array}{l}0.0008 \\
(0.0010)\end{array}$ \\
\hline cen_mast_y10 & $\begin{array}{l}-0.0012^{* * *} \\
(0.0001)\end{array}$ & $\begin{array}{l}-0.0001 \\
(0.0001)\end{array}$ & $\begin{array}{l}-0.0010^{* * *} \\
(0.0001)\end{array}$ & $\begin{array}{l}-0.0000 \\
(0.0001)\end{array}$ \\
\hline cen_mast_y12 & $\begin{array}{l}-0.0002 * * * \\
(0.0000)\end{array}$ & $\begin{array}{l}0.0012 * * * \\
(0.0002)\end{array}$ & $\begin{array}{l}0.0000 \\
(0.0000)\end{array}$ & $\begin{array}{l}0.0017 * * * \\
(0.0003)\end{array}$ \\
\hline cen_mast_cert & $\begin{array}{l}0.0079 * * * \\
(0.0003)\end{array}$ & $\begin{array}{l}0.0061 * * * \\
(0.0004)\end{array}$ & $\begin{array}{l}0.0109 * * * \\
(0.0004)\end{array}$ & $\begin{array}{l}0.0071 * * * \\
(0.0006)\end{array}$ \\
\hline cen_mast_dip & $\begin{array}{l}-0.0000 \\
(0.0000)\end{array}$ & $\begin{array}{l}-0.0002^{* * *} \\
(0.0001)\end{array}$ & $\begin{array}{l}0.0000 \\
(0.0000)\end{array}$ & $\begin{array}{l}-0.0002 * * * \\
(0.0001)\end{array}$ \\
\hline cen_mast_bach & $\begin{array}{l}-0.0017^{* * *} \\
(0.0001)\end{array}$ & $\begin{array}{l}-0.0027 * * * \\
(0.0006)\end{array}$ & $\begin{array}{l}-0.0022^{* * *} \\
(0.0002)\end{array}$ & $\begin{array}{l}0.0000 \\
(0.0013)\end{array}$ \\
\hline cen_phd_y10 & $\begin{array}{l}-0.0000 * * \\
(0.0000)\end{array}$ & $\begin{array}{l}0.0000 \\
(0.0000)\end{array}$ & $\begin{array}{l}-0.0000 * * \\
(0.0000)\end{array}$ & $\begin{array}{l}0.0000 \\
(0.0000)\end{array}$ \\
\hline cen_phd_y12 & $\begin{array}{l}0.0000^{* *} \\
(0.0000)\end{array}$ & $\begin{array}{l}-0.0001 \\
(0.0000)\end{array}$ & $\begin{array}{l}0.0000^{* *} \\
(0.0000)\end{array}$ & $\begin{array}{l}-0.0000 \\
(0.0000)\end{array}$ \\
\hline cen_phd_cert & $\begin{array}{l}0.0008 * * * \\
(0.0001)\end{array}$ & $\begin{array}{l}0.0002^{* *} \\
(0.0001)\end{array}$ & $\begin{array}{l}0.0010^{* * *} \\
(0.0001)\end{array}$ & $\begin{array}{l}0.0003 * * * \\
(0.0001)\end{array}$ \\
\hline cen_phd_dip & $\begin{array}{l}0.0000 \\
(0.0000)\end{array}$ & $\begin{array}{l}-0.0000 \\
(0.0000)\end{array}$ & $\begin{array}{l}0.0000 * \\
(0.0000)\end{array}$ & $\begin{array}{l}-0.0000 \\
(0.0000)\end{array}$ \\
\hline cen_phd_bach & $\begin{array}{l}0.0013^{* * * *} \\
(0.0001)\end{array}$ & $\begin{array}{l}-0.0004^{*} \\
(0.0003)\end{array}$ & $\begin{array}{l}0.0017 * * * \\
(0.0001)\end{array}$ & $\begin{array}{l}0.0002 \\
(0.0004)\end{array}$ \\
\hline Total & 0.0030 & 0.0149 & 0.0067 & 0.0328 \\
\hline Constant & $\begin{array}{l}-0.0788 * * * \\
(0.0221)\end{array}$ & & $\begin{array}{l}-0.1296 * * * \\
(0.0249)\end{array}$ & \\
\hline Observations & 569,325 & & 569,325 & \\
\hline
\end{tabular}

Notes: Standard errors are presented in parentheses. ${ }^{*}, * *$ and $* * *$ denote significance at the ten, five and one per cent levels, respectively. Panels (iii) and (iv) present results of the two-fold decomposition with deviation contrast coding. 
Figure 1 - Proportion of Appropriately Trained Workers by Gender, 1999-2009

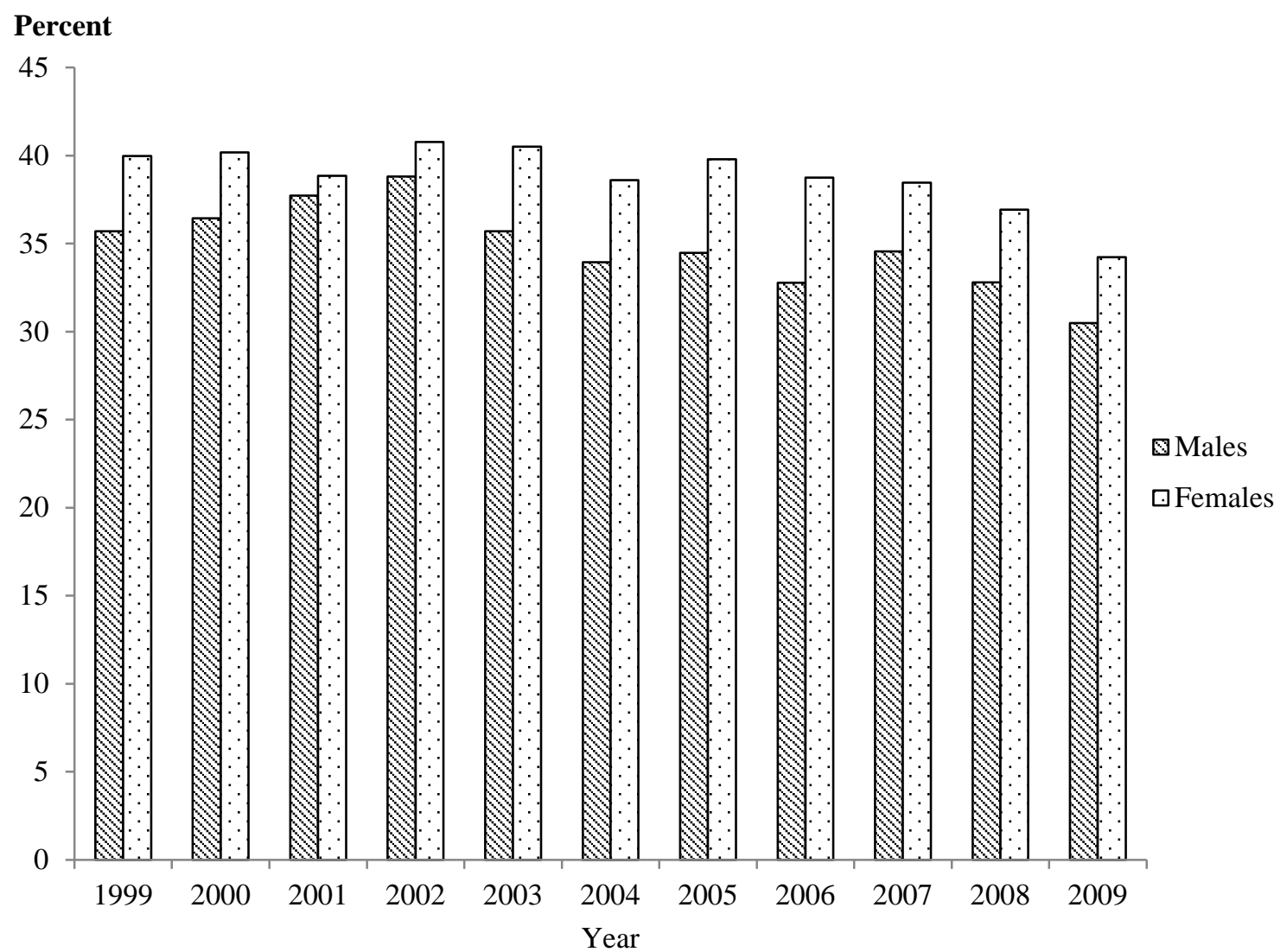

